Review

\title{
The Application of Single-Cell Ingredients in Aquaculture Feeds-A Review
}

\author{
Brett D. Glencross ${ }^{1, *(D)}$, David Huyben ${ }^{1,2}$ and Johan W. Schrama ${ }^{3}$ \\ 1 Institute of Aquaculture, University of Stirling, Stirling FK9 4LA, UK; david.huyben1@stir.ac.uk \\ 2 Department of Animal Biosciences, University of Guelph, Guelph, ON N1G 2W1, Canada \\ 3 Aquaculture and Fisheries Group (AFI), Wageningen University and Research, \\ 6700 HB Wageningen, The Netherlands; johan.schrama@wur.nl \\ * Correspondence: b.d.glencross@stir.ac.uk
}

Received: 1 June 2020; Accepted: 30 June 2020; Published: 16 July 2020

\begin{abstract}
Single-cell ingredients (SCI) are a relatively broad class of materials that encompasses bacterial, fungal (yeast), microalgal-derived products or the combination of all three microbial groups into microbial bioflocs and aggregates. In this review we focus on those dried and processed single-cell organisms used as potential ingredients for aqua-feeds where the microorganisms are considered non-viable and are used primarily to provide protein, lipids or specific nutritional components. Among the SCI, there is a generalised dichotomy in terms of their use as either single-cell protein (SCP) resources or single-cell oil (SCO) resources, with $\mathrm{SCO}$ products being those oleaginous products containing $200 \mathrm{~g} / \mathrm{kg}$ or more of lipids, whereas those products considered as SCP resources tend to contain more than $300 \mathrm{~g} / \mathrm{kg}$ of protein (on a dry basis). Both SCP and SCO are now widely being used as protein/amino acid sources, omega-3 sources and sources of bioactive molecules in the diets of several species, with the current range of both these ingredient groups being considerable and growing. However, the different array of products becoming available in the market, how they are produced and processed has also resulted in different nutritional qualities in those products. In assessing this variation among the products and the application of the various types of SCI, we have taken the approach of evaluating their use against a set of standardised evaluation criteria based around key nutritional response parameters and how these criteria have been applied against salmonids, shrimp, tilapia and marine fish species.
\end{abstract}

Keywords: raw materials; bacteria; microalgae; fungal; yeast; biofloc; protein; oils

\section{Introduction}

Single-cell ingredients (SCI) are a relatively broad class of materials that encompasses bacterial, fungal (yeast), microalgal derived products or combinations of all three in some cases. A distinction is made in this review between single-cell organisms used as ingredients and those used as probiotics, in that this review focuses solely on those dried and/or processed SCI that are non-viable and are used to provide protein, lipids or specific nutritional components that are not related to the microbial viability of the material. The use of such resources as feed ingredients is not new with studies dating back to the 1970s reporting the application of each in the feeds of aquaculture species [1-4]. However, the current potential utility of these ingredients is considerable and growing [5]. They are now being used as protein/amino acid sources, omega-3 sources and sources of bioactive molecules like astaxanthin and peptidoglycans [6,7]. Most activity in recent years has been in the production of protein and omega- 3 sources from these materials as increasing competition drives up the prices for these nutrients in the global market place $[5,8-10]$. However, the different array of products becoming available in the market, produced and processed using different techniques and strategies, has also 
resulted in different nutritional qualities in those products [5,11-15]. Additionally, the combination of all three microbial groups into microbial bioflocs and aggregates is another emerging area attracting some interest as another way of producing such SCI resources [16,17]. For an overview of the various production systems used and current state of commercial development, see the review of Jones et al. [5]. This present review, however, focuses on the various levels of nutritional assessment of the current range of single-cell protein (SCP) and single-cell oil (SCO) products, including some of the various applications of bioflocs as SCI.

In assessing the utility of various types of SCP and SCO there is some logic to evaluating their application against a set of standardised evaluation criteria based around various nutritional response parameters. Such an evaluation of the application of these ingredients is based around the recommendations suggested by Glencross [18]. Based on those recommendations a series of seven steps are applied: Step 1. Characterisation; Step 2. Palatability; Step 3. Digestibility; Step 4. Utilisation; Step 5. Immunological; Step 6. Processing Effects; and Step 7. Product Quality Influences. In applying each of these seven steps, a formulator can then make the appropriate choice as to whether to use any particular ingredient, and the necessary constraints to impose on their use. Missing any one of these steps increases the risk exposure as the formulator needs to make a greater number of unsubstantiated assumptions [10].

\section{Characterisation}

The primary point of any characterisation deals with the identification of the material. This needs to encompass not only what the material is (taxonomically), preferably down to strain (breed) level, as significant variability in various characteristics have been recognised within species, but between strains, but also where the material comes from, who the producer and/or supplier is and what processes may have been used in the ingredient's production [19]. Across each of the three main taxonomic groups examined (microalgae, fungi and bacteria) there has been, arguably, a predominance of work with microalgae $[14,15,20,21]$. Despite the predominance of work with microalgae, there has also been considerable application of both yeasts and bacteria as protein, lipid or bioactive resources. In Table 1 it can be seen that a wide variety of microalgal phyla have been used and an even greater range of species. More constrained have been both the yeasts and bacterial products. In some cases, recent studies with microbial flocs have reported some promising compositional parameters and novel bioactive effects, but the highly complex species structure of these microbial aggregates has meant that they are rarely very well defined taxonomically $[22,23]$. Less documented, however, has been the composition of many of the different resources, in many cases even a basic nutritional profile of the SCP and SCO ingredients missing from many of the nutritional studies reported. The absence of this data makes it difficult to place the assessment of the ingredient in context with the broader range of materials available throughout the world and/or compare across studies. In terms of distinguishing between SCP and SCO resources a distinction being proposed is that SCO products are generally regarded as those oleaginous products containing $200 \mathrm{~g} / \mathrm{kg}$ or more of lipids, whereas those products considered as SCP resources tend to contain more than $300 \mathrm{~g} / \mathrm{kg}$ of protein, both expressed on dry basis [24]. Based on this approach it can be seen that most SCO resources are usually of a microalgal origin, although there are some fungal sources as well. By contrast, SCP can be produced from all four microbial groups (Figure 1).

There are several reviews already that deal with the specific application of microalgal resources in the feeds for aquaculture species [25-27]. Production of microalgal SCI is not a new area, however, with production of various products being long established since the early to mid-20th century. Products such as Dunaliella and Haematococcus were among the early successful products based on their high-value carotenoid content [28,29]. New microalgal resources have attracted much attention in recent years, particularly as sources of long-chain omega-3 polyunsaturated fatty acids (PUFA), where arguments have been mounted about "cutting out the middle-fish" in the feed chain by feeding such microalgal products directly to aquaculture species rather than harvesting forage fish that 
naturally feed on these resources [30]. Whether there is sustainable logic to that argument or not, remains another question, but these resources are certainly progressing both in terms of becoming reliable sources of protein and omega-3 nutrients [31]. Key microalgal genera being developed and commercialised for their omega-3 potential include; Schizochytrium, Nannochloropsis and Crythecodnium among others [32-34]. Not all microalgal sources are suitable sources of omega-3 nutrients, however, with some microalgal resources actually being quite high in omega- 6 fatty acids. Consequently, a similar amount of focus has also been placed on using these microbial resources to produce protein, from sources including Chlorella and Nannochloropsis [35,36]. However, certain challenges have been identified in their application to feeds and the required processing of the microalgae in order to improve their nutritional value has been a current focus $[14,15,37]$. Another focus that has important ramifications for the characterisation is the production system and conditions used to produce the various microalgal resources, as this has been shown to be an influential factor in the resultant nutritional composition of the various products [38].

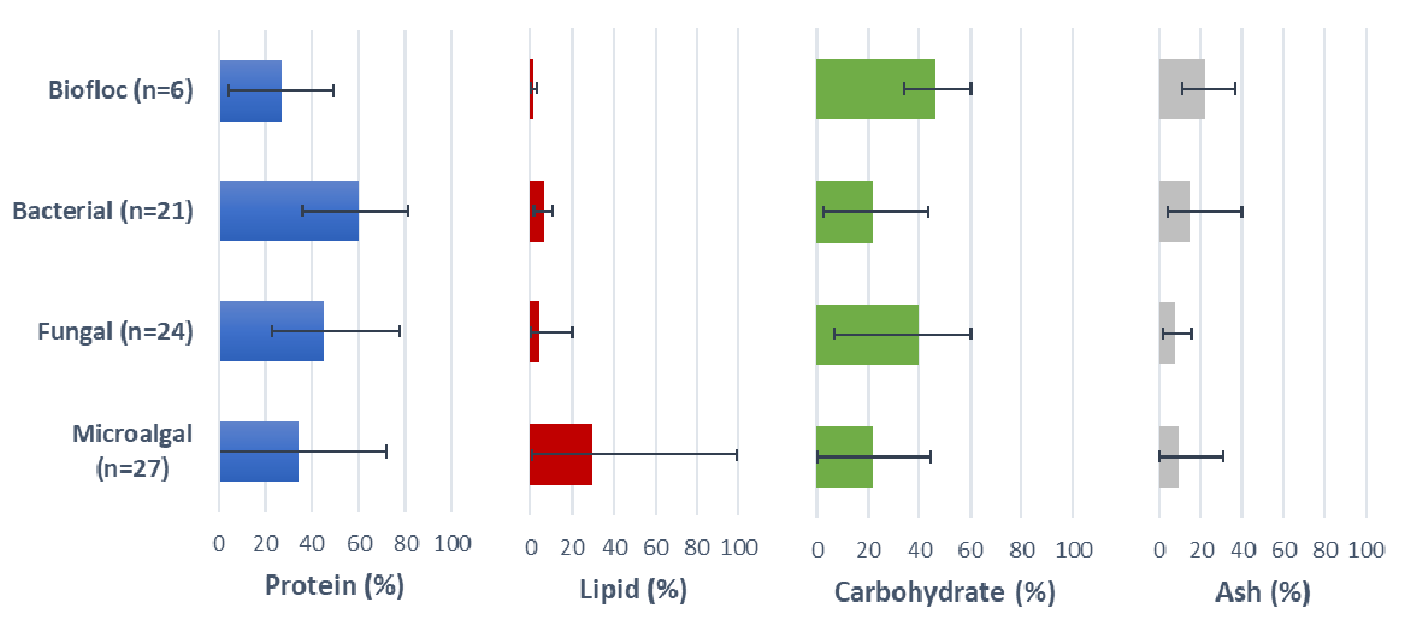

Figure 1. Summary of the proximate composition (\% dry basis) of the range of microalgal, fungal, bacterial and biofloc resources reported as feed ingredients in aquaculture. Shown are the number of different products characterised, the mean composition parameters in each group as well as the upper and lower ranges.

Fungal SCP resources fall into two categories, unicellular (yeast) and filamentous fungi, of which yeast has been more prominent in aquaculture research and several reviews exist [39,40]. Baker's yeast is produced from a molasses substrate mainly for the baking industry and is used in aquafeeds, although its live form is inactivated by high heat and pressure during feed extrusion [41]. Due to high demand for food production, baker's yeast can be more expensive compared to yeast by-products (waste) produced from the biofuel and brewing industries [42]. Distiller's dried grain yeast (DDGY) is a by-product from the biofuel industry during the production of ethanol whereas brewer's yeast is filtered in the final stages of brewing beer and wine before inactivation by organic acids and then dried. Saccharyomces cerevisiae is the most common species of yeast, although DDGY, brewer's yeast and baker's yeast are different strains related to taste and alcohol production [43]. Hundreds of yeast species exist while only a small handful are used in aquafeeds, such as Saccharomyces cerevisiae, Candida utilis, Kluyveromyces marxianus, Phaffia rhodozyma and Wickerhamomyces anomalus, which act as sources of protein, lipids, pigment and enzymes.

Yeasts are used as supplements in animal feeds due to their relatively high protein and amino acid, energy, and micronutrient content compared with common feed grains and oilseed meals [43]. However, intact yeast have a thick cell wall that can resist digestive enzymes and reduce digestibility, thus several studies have homogenised yeast cells (e.g., centrifugation) and removed cell walls in order to increase feed digestibility with yeast extracts [44]. The only disadvantage is that yeast cell walls contain high levels of mannan-oligosaccharides (MOS), beta-glucans, chitin and nucleotides that act as 
prebiotic fibres and immune-stimulants for several fish species [45]. Similar to microbial and algal SCPs, production conditions, such as temperature, drying time, organic substrate, harvesting time, storage and yeast strain can result in variation in protein, lipid, and other nutrient composition [42].

Most bacterial SCI tend to fall into categories of bacterial SCP (e.g., Methylococcus capsulatus; FeedKind ${ }^{\mathrm{TM}}$ ) or SCI that are produced for a particular bioactive compound such as astaxanthin (e.g., Paracoccus carotinifaciens; Panaferd-AX ${ }^{\mathrm{TM}}$ ). Of those bacterial resources used to produce protein, they tend to be one of three genera; Spirulina, Methylococcus or Methylophilus [8]. In contrast to microalgal and fungal SCI, there appears to be little secondary processing of these products other than drying, although clearly there is a range of variables involved in the production process that affect the nutritional composition of the various products $[1,46]$. No studies examining any bacterial $\mathrm{SCO}$ resources were found during our review of the literature. This is most likely linked to the observation that bacteria are generally not very prolific producers of triglycerides [47]. In fact, in many bacteria energy is stored as polyhydroxyalkanoate [48]. An example is polyhydroxybutarate, which has immune modulating properties, can alter microbial community and is also often present in biofloc [49].

Table 1. Major groups of microalgae, yeasts and bacteria used as single-cell protein (SCP) or single-cell oil (SCO) source ingredients in aquaculture feeds.

\begin{tabular}{|c|c|c|c|c|c|c|}
\hline Group & (Super)Phylum & Class & Genus & Species & Application & Data Source \\
\hline \multirow{6}{*}{ Microalgae } & Chlorophyta & Chlorophyceae & Haematococcus & pluvialis & Bioactive & [51] \\
\hline & \multirow{3}{*}{ Heterokonta } & Eustigmatophyceae & Nannochloropsis & gaditana & SCP & [15] \\
\hline & & Coscinodiscophyceae & Chaetoceros & muelleri & $\mathrm{SCO}$ & [54] \\
\hline & & Coscinodiscophyceae & Skeletonema & costatum & $\mathrm{SCO}$ & [55] \\
\hline & Haptophyta & Prymnesiophyceae & Isochrysis & galbana & $\mathrm{SCO}, \mathrm{SCP}$ & {$[32,57]$} \\
\hline & Dinoflagellata & Dinophyceae & Crypthecodinium & cohnii & SCO & [20] \\
\hline \multirow[t]{3}{*}{ Fungal } & \multirow[t]{3}{*}{ Ascomycota } & Saccharomycetes & Saccharomyces & cerevisiae & SCP & {$[41,58]$} \\
\hline & & Saccharomycetes & Wikerhamomyces & anomalus & SCP & {$[41,59]$} \\
\hline & & Saccharomycetes & Candida & utilis & SCP & [58] \\
\hline \multirow{2}{*}{ Bacteria } & & Betaproteobacteria & Methylophilus & methylotrophus & SCP & [63] \\
\hline & & Alphaproteobacteria & Methylobacterium & extorquens & SCP & [64] \\
\hline
\end{tabular}

In contrast to most of the other SCI resources examined in this review, bioflocs differ in that they represent a heterogenous mix of each of the other single-cell resources, combined with by-products from each $[16,17,65]$. Various studies have been undertaken examining different aspects of biofloc production and their characteristics can be highly diverse depending on the various production parameters employed [66,67]. Although there are many studies examining the application of microbial biofloc in situ in ponds for shrimp and other species [68-71], we make the distinction in this review as them being those microbial bioflocs that are harvested and then included into diets for the animals being fed. This way some distinction can be made over the planned rather than ad hoc nutritional processes that occur. Most such biofloc studies have focused on protein production based on utilising in-situ nitrogenous inputs and added carbon inputs to fuel the microbial productivity [72,73]. Notably, no studies were found where biofloc had been used to create a viable SCO resource, but several were reported where nutritional components other than protein were produced [74-77].

\subsection{Proteins and Amino Acids}

In SCPs the main value lies in the total protein content of these resources. There is some value in the specific amino acid profile of these resources as well, but that is arguably a somewhat secondary consideration to the total protein content, as the amino acid balance of feeds can invariably be easily 
manipulated in practice via the co-use of other protein resources or the inclusion of small amounts of crystalline amino acids. Notably, no protein source is likely to be used as a sole source in any case, with constraints to inclusion levels meaning that the contribution of individual ingredient to the diet's amino acid profile is somewhat also constrained. In SCOs the protein is arguably of secondary importance, but in some resources this protein level is still appreciable [8,78,79].

A wide range of protein levels can be observed within and among the different groups (Figure 1; Table 2). Microalgal ingredient protein levels ranged from $0 \%$ to $\sim 60 \%($ mean $=34 \%)$, although this was largely dependent on the level of processing used to prepare the ingredient. In some cases, the lower protein levels were associated with higher lipid levels, or even pure oil products, with those products often being touted primarily as an omega-3 (lipid) source. Fungal ingredient protein levels were relatively consistent at between $30 \%$ and $60 \%$ (mean $=45 \%$ ), but rarely higher. Protein levels in the bacterial SCP were generally the highest among the different SCP examined, with some products containing protein levels as high as $80 \%$ (mean $=60 \%$ ). Biofloc resources tended to contain the least protein $($ mean $=27 \%)$, with some products containing very low levels of protein $(<5 \%)$, that were generally not touted as "protein sources" per se, but reputed to deliver other nutritional benefits. Biofloc and microalgal SCIs can have high ash contents when cultured in saline conditions and depending on the process conditions (Figure 1).

The amino acid composition of microalgal SCP varied depending on the resource used. Among the various microalgal resources examined, the essential amino acid (EAA) levels showed abundant levels of leucine and lysine, although they were relatively deficient in histidine (Table 2). The amino acid composition of fungal SCP resources from various different genera of yeast; Saccharomyces, Candida and Wikerhamomyces, while not overly rich in protein (range of $33 \%$ to $47 \%$ ), were particularly rich in glutamic acid (except for Candida) and among the essential amino acids were also rich in lysine and leucine, but very low in methionine, tryptophan and arginine. The amino acid composition of the various bacterial SCP resources reported were comparatively high, with a much more uniform level of each of the EAA and also the non-EAA (Table 2). Among the EAA, leucine was typically the most abundant amino acid, followed by lysine and valine. In contrast to the other resources, methionine was relatively abundant in the bacterial SCPs $[8,62]$. Another notable feature of the bacterial SCP resources was the difference between the two different estimates of protein, with crude protein $(\mathrm{N} \times 6.25)$ being consistently much higher than the sum of amino acids. In the microalgae, Nannochloropsis gaditana, Tetraselmis impellucida, and Scenedesmus dimorphus the sum of amino acids was, respectively, $77 \%$, $72 \%$ and $62 \%$ [15]. Teuling et al. [15] demonstrated that different protein isolations steps can alter the ratio between total sum of amino acids and crude protein estimates. Sum of amino acid protein levels in the fungal SCP were typically $85 \%$ to $95 \%$ of the crude protein estimate, whereas the bacterial SCP were only $79 \%$ to $84 \%$ of the crude protein estimate. This is likely due to the high nucleotide content of the bacterial SCP which contributes a much higher level of non-protein nitrogen than the other resources [81]. The carbohydrate content (Table 2) is often calculated as dry matter minus crude protein minus ash minus fat. Consequently, the large difference between the sum of amino acids and crude protein $(\mathrm{N} \times 6.25)$ in various $\mathrm{SCI}$ implies that the carbohydrate content is often underestimated. 
Table 2. Proximate and Amino Acid analysis of various SCP resources. All values \% as supplied unless otherwise detailed.

\begin{tabular}{|c|c|c|c|c|c|c|c|c|c|}
\hline $\begin{array}{c}\text { Group } \\
\text { Species } \\
\text { Material } \\
\text { Data Source }\end{array}$ & $\begin{array}{c}\text { Microalgal } \\
\text { Chlorella } \\
\text { Biomass } \\
{[36]}\end{array}$ & $\begin{array}{c}\text { Microalgal } \\
\text { Nannochloropsis } \\
\text { Biomass } \\
{[35]}\end{array}$ & $\begin{array}{c}\text { Fungal } \\
\text { Saccharomyces } \\
\text { Biomass } \\
{[41]}\end{array}$ & $\begin{array}{c}\text { Fungal } \\
\text { Wikerhamomyces } \\
\text { Biomass } \\
{[41]}\end{array}$ & $\begin{array}{c}\text { Fungal } \\
\text { Candida } \\
\text { Biomass } \\
{[80]}\end{array}$ & $\begin{array}{c}\text { Bacterial } \\
\text { Spirulina } \\
\text { Biomass } \\
{[36]}\end{array}$ & $\begin{array}{c}\text { Bacterial } \\
\text { Methylophilus } \\
\text { Biomass } \\
{[5]}\end{array}$ & $\begin{array}{c}\text { Bacterial } \\
\text { Methylococcus } \\
\text { Biomass } \\
{[62]}\end{array}$ & $\begin{array}{c}\text { Bacterial } \\
\text { Methylobacterium } \\
\text { Biomass } \\
{[64]}\end{array}$ \\
\hline Dry matter & 95.0 & 94.9 & 94.0 & 93.0 & 96.4 & 82.2 & 100 & 98.6 & 96.3 \\
\hline Moisture & 5.0 & 5.1 & 6.0 & 7.0 & 3.6 & 17.8 & 0.0 & 1.4 & 3.7 \\
\hline Protein & 54.5 & 47.7 & 46.6 & 42.2 & 33.3 & 61.3 & 81.3 & 68.1 & 50.9 \\
\hline Lipid & 9.4 & 8.4 & 1.0 & 0.9 & 2.1 & 5.5 & 7.2 & 10.4 & 0.8 \\
\hline Ash & 5.3 & 7.5 & 6.3 & 7.0 & 9.8 & 6.9 & 9.1 & 8.0 & 4.1 \\
\hline Carbohydrates & 25.8 & 31.3 & 40.1 & 42.9 & 51.2 & 8.5 & 2.4 & 12.1 & 40.5 \\
\hline Energy $(\mathrm{kJ} / \mathrm{g})$ & 20.9 & 19.9 & 18.3 & 17.7 & 17.5 & 18.1 & 22.4 & 22.2 & 19.3 \\
\hline Sum Amino Acids & - & 37.6 & 42.4 & 36.0 & 31.7 & - & 68.2 & 55.9 & 42.9 \\
\hline Alanine & - & 2.5 & 2.3 & 2.0 & 2.1 & - & 5.8 & 4.4 & 3.8 \\
\hline Arginine & 2.9 & 2.3 & 2.0 & 1.6 & 1.7 & 4.1 & 3.7 & 3.8 & 3.3 \\
\hline Aspartic acid & - & 3.3 & 3.5 & 3.1 & 3.4 & - & 7.2 & 5.5 & 4.4 \\
\hline Cysteine & - & 0.3 & 0.0 & 0.0 & 0.3 & - & 0.6 & 0.5 & 0.3 \\
\hline Glutamic acid & - & 4.6 & 13.2 & 11.4 & 4.3 & - & 8.6 & 6.5 & 6.3 \\
\hline Glycine & - & 1.8 & 1.2 & 0.9 & 1.6 & - & 4.6 & 3.1 & 2.5 \\
\hline Histidine & 1.0 & 0.7 & 0.9 & 0.7 & 0.6 & 1.0 & 1.5 & 1.3 & 1.1 \\
\hline Isoleucine & 1.5 & 1.7 & 1.9 & 1.6 & 1.7 & 2.6 & 3.5 & 2.7 & 1.7 \\
\hline Leucine & 4.2 & 3.2 & 3.1 & 2.6 & 2.6 & 4.7 & 5.7 & 5.0 & 3.3 \\
\hline Lysine & 4.6 & 2.3 & 3.3 & 2.7 & 2.3 & 3.1 & 4.9 & 3.5 & 2.5 \\
\hline Methionine & 1.0 & 0.9 & 0.3 & 0.2 & 0.4 & 1.4 & 2.0 & 1.5 & 0.9 \\
\hline Phenylalanine & 2.3 & 1.9 & 2.2 & 1.8 & 1.5 & 2.5 & 3.3 & 3.0 & 2.0 \\
\hline Proline & - & 4.7 & 1.8 & 1.5 & 1.4 & - & 2.4 & 2.5 & 1.9 \\
\hline Serine & - & 1.6 & 1.3 & 1.5 & 1.9 & - & 2.7 & 2.4 & 1.9 \\
\hline Taurine & - & 0.0 & 0.0 & 0.2 & - & - & - & - & - \\
\hline Threonine & 2.0 & 1.7 & 1.6 & 1.5 & 2.1 & 2.7 & 3.7 & 2.8 & 2.0 \\
\hline Tryptophan & 1.5 & 0.8 & 0.0 & 0.0 & 0.5 & 1.2 & 0.7 & 1.3 & - \\
\hline Tyrosine & - & 1.1 & 1.6 & 1.4 & 1.1 & - & 2.8 & 2.2 & 1.4 \\
\hline Valine & 2.4 & 2.2 & 2.5 & 2.0 & 2.1 & 0.3 & 4.6 & 3.7 & 2.8 \\
\hline
\end{tabular}




\subsection{Lipids and Others (Astaxanthin and Bioactives)}

In contrast to SCPs, in SCOs the main value lies less so in the total lipid content of these resources, but rather in the specific fatty acid profile of that lipid. This is not to underestimate the intrinsic value of the total lipid abundance, but rather that the specific point of difference that SCOs have against many other ingredients available is their relatively unique content of long-chain omega-3 long-chain polyunsaturated fatty acids (LC-PUFA) $[7,78,79]$.

The total lipid content of some of the SCO resources at $>50 \%$ lipid (Table 3 ), is incredibly high for a biological cell, perhaps matched only by some crop seeds (e.g., rapeseed). In contrast, many of the SCP resources are quite low $(<5 \%)$ in lipid [8] (Table 2). Those resources produced from bacteria tend to be quite low in lipid in particular, reflecting the focus of many of these resources on the protein side of the story [8].

A clear focus on the SCO has been towards n-3 LC-PUFA production and accordingly, many of those resources developed have high levels of these fatty acids (Table 3). For example, some species of microalgae, like Nannochloropsis have levels of eicosapentaenoic acid (20:5n-3; EPA) in excess of $30 \%$ of total fatty acids (TFA), whereas species such as Crypthecodinium and Schizochytrium have docosahexaenoic acid (22:6n-3; DHA) levels in excess of 40\%TFA [32,34,38,82,83]. Total lipid levels in both fungal and bacterial ingredients have tended to be somewhat lower and as such there has been less of a focus on the fatty acid profile of these resources. Despite that, there have been reports of varieties of genetically modified oleaginous yeasts enriched with EPA ( $>30 \%$ TFA) containing lipid levels exceeding $20 \%[84,85]$.

Not only were there substantial differences among different microalgal resources on the fatty acid profiles and total lipid levels, but different production and processing methods were also very influential in affecting fatty acid and lipid composition of the materials [78,82]. Variables such as temperature, salinity, nitrogen-source and carbon-source were found to be very influential in production $[38,89]$. The use of genetic manipulation has also been applied in some instances to improve both productivity and total lipid yields [90]. Following production variables, the different approaches used in processing are also very influential on composition, with in some cases, complete oil extracts being produced, whereas in other cases an oil-rich biomass was produced [91].

In addition to the primary macronutrients of protein and lipid (and their associated components of amino and fatty acids respectively), SCI also contribute other nutrients that bring certain nutritional values. For example, there are varieties of microalgae, such as Haematococcus pluvialis (NaturRose ${ }^{\mathrm{TM}}$ ) that have been developed and are being used as natural sources of the carotenoid astaxanthin $[92,93]$. Similarly, there are bacterial (Paracoccus carotinifaciens; Panaferd-AX ${ }^{\mathrm{TM}}$ ) and fungal (Phaffia rhodozyma; RedStar ${ }^{\mathrm{TM}}$ ) resources also being commercially used as astaxanthin sources [94]. In addition to carotenoids, other valuable bioactive nutrients such as nucleotides and peptidoglycans have also been developed from various SCI resources [95]. Bacterial peptidoglycans (e.g., Sanictum ${ }^{\mathrm{TM}}$ ) are a relatively little studied additive that are reputed to provide some stimulation of the immune system in fishes $[96,97]$ and shrimp $[67,98]$. However, considerably more work has been reported on the application of nucleotide enrichments produced from yeast and bacterial sources Li and Gatlin [95]. Both bacterial and yeast SCP resources have reportedly had levels of nucleotides as high as $15.9 \%$ of the biomass, making them among the richest sources of these nutrients [8]. 
Table 3. Total lipid and fatty acid profiles (\% of total fatty acids) of various SCO resources.

\begin{tabular}{|c|c|c|c|c|c|c|c|c|}
\hline $\begin{array}{c}\text { Group } \\
\text { Species } \\
\text { Material } \\
\text { Data Source }\end{array}$ & $\begin{array}{c}\text { Microalgal } \\
\text { Schizochytrium } \\
\text { Biomass } \\
{[86]}\end{array}$ & $\begin{array}{c}\text { Microalgal } \\
\text { Schizochytrium } \\
\text { Oil } \\
{[34]}\end{array}$ & $\begin{array}{c}\text { Microalgal } \\
\text { Crypthecodinium } \\
\text { Biomass } \\
\text { [33] }\end{array}$ & $\begin{array}{c}\text { Microalgal } \\
\text { Chlorella } \\
\text { Whole-cell } \\
\text { [87] }\end{array}$ & $\begin{array}{c}\text { Microalgal } \\
\text { Isochrysis } \\
\text { Biomass } \\
\text { [88] }\end{array}$ & $\begin{array}{c}\text { Microalgal } \\
\text { Pavlova } \\
\text { Biomass } \\
\text { [32] }\end{array}$ & $\begin{array}{c}\text { Microalgal } \\
\text { Nannochloropsis } \\
\text { Biomass } \\
\text { [32] }\end{array}$ & $\begin{array}{c}\text { Fungal } \\
\text { Yarrowia } \\
\text { Biomass } \\
\text { [84] }\end{array}$ \\
\hline Dry matter & 98.4 & 98.9 & 100.0 & 96.4 & 100.0 & - & - & 95.3 \\
\hline Moisture & 1.6 & 1.1 & - & 3.6 & 0.0 & - & - & 4.7 \\
\hline Protein & 13.2 & 0.0 & - & 30.4 & 29.5 & - & - & 29.8 \\
\hline Lipid & 61.4 & 98.6 & 50.0 & 26.0 & 23.4 & - & - & 20.3 \\
\hline Ash & 4.4 & 0.3 & - & 3.3 & 13.2 & - & - & 2.1 \\
\hline Carbohydrate & 19.4 & 0.0 & - & 36.7 & 33.9 & - & - & 43.1 \\
\hline Energy & 28.8 & 39.1 & - & 23.5 & 21.8 & - & - & 22.3 \\
\hline \multicolumn{9}{|l|}{ Fatty Acids } \\
\hline C14:0 & 4.1 & 12.0 & 16.0 & 0.7 & 17.3 & 10.0 & 4.8 & 0.3 \\
\hline C15:0 & 2.0 & 1.5 & 0.1 & 0.1 & 0.0 & 0.2 & 0.5 & - \\
\hline $\mathrm{C} 16: 0$ & 52.8 & 26.3 & 25.0 & 17.1 & 12.0 & 20.8 & 20.3 & 10.7 \\
\hline $\mathrm{C} 18: 0$ & 1.5 & 0.9 & 0.0 & 1.9 & 1.1 & 0.2 & 0.3 & 6.6 \\
\hline C20:0 & 0.2 & 0.0 & 0.0 & 0.2 & - & - & - & 0.7 \\
\hline C22:0 & 0.1 & 0.0 & 0.0 & 0.1 & - & - & - & 1.0 \\
\hline Total Saturates & 61.4 & 41.9 & 41.1 & 21.1 & 30.3 & 31.2 & 26.2 & 19.3 \\
\hline C16:1n-7 & 0.1 & 4.5 & 0.4 & 1.6 & 3.1 & 19.9 & 21.2 & 1.5 \\
\hline C18:1n-9 & 0.1 & 0.7 & 16.0 & 30.6 & 6.9 & 0.5 & 4.1 & 8.8 \\
\hline $\mathrm{C} 18: 1 \mathrm{n}-7$ & - & 2.9 & - & 0.5 & 1.1 & 3.3 & 0.5 & \\
\hline C20:1n-11 & 0.1 & 0 & - & - & - & - & - & 0.2 \\
\hline C22:1n-11 & 0.2 & 0 & - & - & - & - & - & 0.9 \\
\hline Total Monoenes & 0.8 & 8.1 & 16.4 & 42.1 & 11.3 & 23.8 & 27.0 & 11.4 \\
\hline C18:2n-6 & 0.1 & 0.3 & 0.5 & 19.7 & 4.0 & 0.4 & 1.8 & 22.9 \\
\hline C18:3n-6 & 0.0 & 0.0 & 0.0 & - & 1.0 & 0.2 & 1.0 & \\
\hline$C 20: 2 n-6$ & 0.1 & 0.0 & 0.0 & - & - & - & - & 2.7 \\
\hline$C 20: 3 n-6$ & 0.1 & 0.0 & 0.0 & - & - & - & - & 3.3 \\
\hline$C 20: 4 n-6$ & 0.3 & 0.0 & 0.0 & - & 0.0 & 0.6 & 7.4 & 0.5 \\
\hline C22:4n-6 & 0.0 & 0.0 & 0.0 & 0.0 & - & - & - & \\
\hline C22:5n-6 & 6.9 & 7.5 & 0.0 & 0.1 & 2.1 & 0.9 & - & \\
\hline Total n-6 PUFA * & 7.4 & 7.8 & 0.5 & 25.6 & 7.1 & 2.1 & 10.2 & 29.4 \\
\hline C18:3n-3 & 0.0 & 0.0 & 0.4 & 13.6 & 5.7 & 1.1 & - & 2.3 \\
\hline$C 18: 4 n-3$ & 0.0 & 0.2 & 0.0 & 0.1 & 19.0 & 6.6 & - & 0.3 \\
\hline C20:4n-3 & 0.1 & 0.4 & 0.0 & 0.1 & - & - & - & 3.5 \\
\hline C20:5n-3 & 0.3 & 0.8 & 0.1 & - & 0.9 & 22.9 & 34.7 & 30.2 \\
\hline C22:5n-3 & 0.1 & 0.0 & 0.0 & - & 0.0 & 0.1 & - & 0.9 \\
\hline C22:6n-3 & 28.5 & 40.9 & 39.0 & - & 9.9 & 7.9 & - & 0.0 \\
\hline Total n-3 PUFA & 29.0 & 42.2 & 39.5 & 14.5 & 35.5 & 38.6 & 34.7 & 37.2 \\
\hline
\end{tabular}

“-": Not Specified. *: polyunsaturated fatty acids. 


\section{Digestibility}

The digestibility of a range of SCP and SCO resources has been reported throughout the literature (Tables 4 and 5). However, a range of problems has been observed among the SCI resources in terms of their digestibilities. In many microalgal SCP resources, problems have been encountered with protein digestibility, with various studies focusing on different methods of processing the microalgae to improve the digestibility (Table 4). While protein digestibility values as high as $99 \%$ have been reported, most are usually somewhat lower (54-87\%; mean \pm standard deviation (SD) $=76 \pm 14 \%$, $\mathrm{n}=18)[15,36,99-101]$. Significant differences have also been reported between different varieties of microalgal SCP, with an Isochrysis SCP $(87 \%)$ having a much better protein digestibility than a Nannochloropsis SCP (69\%/73\%), which was better than a Desmodesmus SCP $(54 \%)$ [99,101]. In a study examining the use of Nannochloropsis, Phaeodactylum and Isochrysis SCPs fed to Mink (Mustela vison), Skrede et al. [35] found that inclusion of any of the three SCP (included at 0, 60, 120 or $240 \mathrm{~g} / \mathrm{kg}$ ) had a negative effect on protein digestibility, but the effect with Phaeodactylum was somewhat less than the other two SCPs. A similar effect was also observed on the lipid digestibility of the three $\mathrm{SCPs}$, but this time with inclusion of Nannochloropsis having the biggest impact. Not only between varieties but also within varieties differences in nutrient digestibility can be present. In the studies of Teuling et al. $[15,102]$ equal processing conditions but different strains of Nannochloropsis garditana were used. Between these studies, protein digestibility was $75 \%$ and $62 \%$, respectively, but also other nutrients had different digestibilities.

Several methods have proven successful in improving protein digestibility algal SCP, including extrusion and bead-milling $[15,99,103]$. There is some consistency in the values reported among different fish species with Nannochloropsis having protein digestibility values of $72 \%, 73 \%$ and $69 \%$ reported for S. salar, O. niloticus and O. mykiss respectively, suggesting that effects are more pronounced among the SCP than among the different aquaculture species $[15,99,101]$. A key factor in protein digestibility seems to be the disruption of the algal cell wall.

The protein content of both fungal and bacterial SCP products has typically been more digestible than that of their microalgal counterparts (Table 4). Across a range of products examined, the average digestibilities of fungal $(80 \%)$ and bacterial $(86 \%)$ products were consistently higher than those of the microalgal products $(76 \%)$. Among the different studies examining the digestibility of fungal SCP it was more difficult to reconcile differences in the digestibilities of different products and among the different aquaculture species. The principal problem encountered was that several of the recent studies did not approach the digestibility assessment in a manner that allowed determination of the ingredient digestibilities, only those of the diets [58,59]. As such a comparison across studies becomes a little more difficult, but the relative effect of the SCP is still evident. Of those studies that did focus on the ingredient digestibility, quite variable results have been reported, with protein digestibilities from as low as $41 \%$ for a spray-dried Candida product, to $98 \%$ for an autolysed and extracted Saccharomyces product $[80,105]$. Some differences have been reported in the protein digestibility among the SCP from different fungal species (Candida $>$ Kluyveromyces $>$ Saccharomyces), but other studies show no differences at all between Saccharomyces and Wickerhamomyces products [58,59]. As with the microalgal SCP studies, several studies have focused on processing effects to improve the protein digestibility and found that various methods, like cellular disruption, protein isolation and autolysis all increase protein digestibility from Saccharomyces products [104,105]. 
Table 4. Influence of material and processing on protein digestibility of various SCP products.

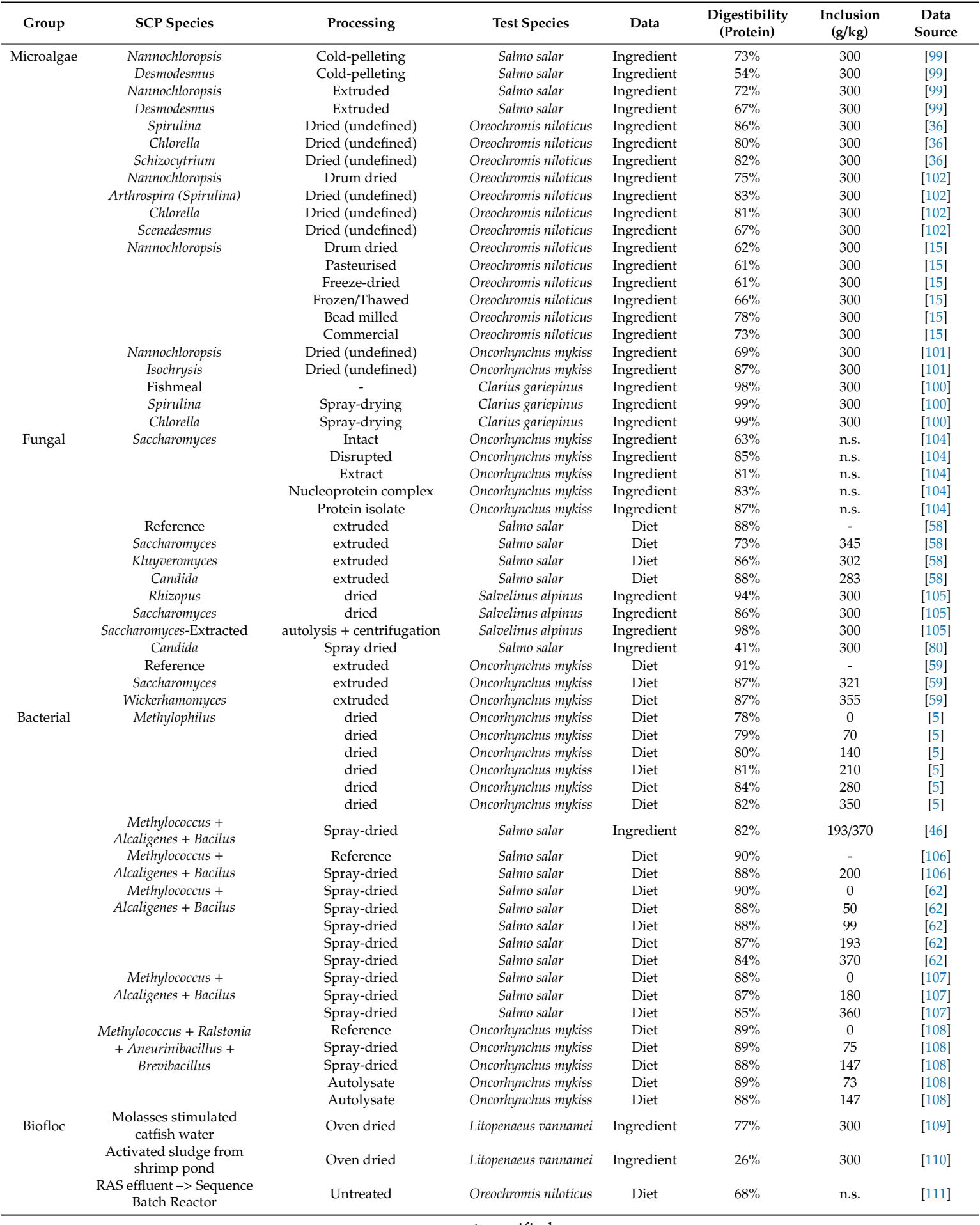


Table 5. Influence of material and processing on lipid and fatty acid class digestibility of various SCO products.

\begin{tabular}{|c|c|c|c|c|c|c|c|c|c|c|c|c|}
\hline \multirow{2}{*}{ Group } & \multirow{2}{*}{ SCO Species } & \multirow{2}{*}{ Material } & \multirow{2}{*}{ Processing } & \multirow{2}{*}{ Test Species } & \multirow{2}{*}{ Data } & \multicolumn{5}{|c|}{ Digestibility } & \multirow{2}{*}{ Inclusion $(\mathrm{g} / \mathrm{kg})$} & \multirow{2}{*}{ Data Source } \\
\hline & & & & & & Total & Sats & Monos & $n-6$ & $n-3$ & & \\
\hline \multirow{3}{*}{ Microalgae } & Schizochytrium & Biomass & Dried & Salmo salar $36 \mathrm{~g}$ & Diet & $94 \%$ & $98 \%$ & $100 \%$ & $100 \%$ & $100 \%$ & 100 & [112] \\
\hline & Canola & Oil & - & Salmo salar $36 \mathrm{~g}$ & Diet & $96 \%$ & $100 \%$ & $100 \%$ & $99 \%$ & $100 \%$ & 169 & [112] \\
\hline & Fish (Jack mackerel) & Oil & - & Salmo salar $36 \mathrm{~g}$ & Diet & $96 \%$ & $99 \%$ & $100 \%$ & $100 \%$ & $100 \%$ & 91 & [112] \\
\hline \multirow[t]{4}{*}{ Microalgae } & Schizochytrium (S) & Oil & Undefined & Salmo salar $40 \mathrm{~g}$ & Diet & - & $71 \%$ & $75 \%$ & $93 \%$ & $97 \%$ & 130 & [113] \\
\hline & Palm & Oil & Undefined & Salmo salar $40 \mathrm{~g}$ & Diet & - & $78 \%$ & $92 \%$ & $95 \%$ & $97 \%$ & 130 & [113] \\
\hline & Palm $+\mathrm{S}$ & Oil & Undefined & Salmo salar $40 \mathrm{~g}$ & Diet & - & $71 \%$ & $91 \%$ & $95 \%$ & $96 \%$ & $104+26$ & [113] \\
\hline & Fish (Jack mackerel) & Oil & Undefined & Salmo salar $40 \mathrm{~g}$ & Diet & - & $76 \%$ & $87 \%$ & $92 \%$ & $96 \%$ & 130 & [113] \\
\hline Microalgae & Schizochytrium & Oil & Enzymatic & Salmo salar $32 \mathrm{~g}$ & Diet & $90 \%$ & $76 \%$ & $92 \%$ & $96 \%$ & $98 \%$ & 90 & [34] \\
\hline \multirow{4}{*}{$\begin{array}{l}\text { Microalgae } \\
\text { +Fungal }\end{array}$} & Schizochytrium + YE & Biomass & Reference & Salmo salar $213 \mathrm{~g}$ & Diet & $96 \%$ & $96 \%$ & $99 \%$ & $99 \%$ & $99 \%$ & 0 & [114] \\
\hline & & Biomass & Dried & Salmo salar $213 \mathrm{~g}$ & Diet & $96 \%$ & $95 \%$ & $99 \%$ & $99 \%$ & $99 \%$ & 10 & [114] \\
\hline & & Biomass & Dried & Salmo salar $213 \mathrm{~g}$ & Diet & $94 \%$ & $86 \%$ & $99 \%$ & $99 \%$ & $99 \%$ & 60 & [114] \\
\hline & & Biomass & Dried & Salmo salar $213 \mathrm{~g}$ & Diet & $88 \%$ & $67 \%$ & $99 \%$ & $99 \%$ & $99 \%$ & 150 & [114] \\
\hline \multirow[t]{3}{*}{ Microalgae } & Schizochytrium & Biomass & Spray-dried & Salmo salar $400 \mathrm{~g}$ & Diet & $94 \%$ & $93 \%$ & $99 \%$ & $99 \%$ & $99 \%$ & 0 & {$[86]$} \\
\hline & & Biomass & Spray-dried & Salmo salar $400 \mathrm{~g}$ & Diet & $93 \%$ & $87 \%$ & $99 \%$ & $99 \%$ & $99 \%$ & 25 & [86] \\
\hline & & Biomass & Spray-dried & Salmo salar $400 \mathrm{~g}$ & Diet & $92 \%$ & $79 \%$ & $99 \%$ & $99 \%$ & $99 \%$ & 50 & [86] \\
\hline \multirow[t]{4}{*}{ Microalgae } & Schizochytrium & Biomass & Spray-dried & Salmo salar $65-270 \mathrm{~g}$ & Diet & $91 \%$ & $78 \%$ & $99 \%$ & $98 \%$ & $99 \%$ & 52 & [115] \\
\hline & & Fishoil & - & Salmo salar $65-270 \mathrm{~g}$ & Diet & $95 \%$ & $96 \%$ & $99 \%$ & $98 \%$ & $99 \%$ & 0 & [115] \\
\hline & & Biomass & Spray-dried & Salmo salar $>860 \mathrm{~g}$ & Diet & $87 \%$ & $63 \%$ & $92 \%$ & $95 \%$ & $96 \%$ & 62 & [115] \\
\hline & & Fishoil & - & Salmo salar $>860 \mathrm{~g}$ & Diet & $85 \%$ & $81 \%$ & $84 \%$ & $90 \%$ & $92 \%$ & 0 & [115] \\
\hline Microalgae & Crypthecodinium & Biomass & Spray-dried & Oncorhynchus mykiss & Ingred. & $98 \%$ & - & - & - & - & 300 & [116] \\
\hline \multirow{3}{*}{ Microalgae } & Spirulina & Biomass & Dried & Oreochromis niloticus & Ingred. & $95 \%$ & $76 \%$ & $76 \%$ & $84 \%$ & - & 300 & {$[36]$} \\
\hline & Chlorella & Biomass & Dried & Oreochromis niloticus & Ingred. & $94 \%$ & $75 \%$ & $70 \%$ & $77 \%$ & $39 \%$ & 300 & [36] \\
\hline & Schizochytrium & Biomass & Dried & Oreochromis niloticus & Ingred. & $98 \%$ & $52 \%$ & $85 \%$ & $92 \%$ & $97 \%$ & 300 & {$[36]$} \\
\hline \multirow[t]{4}{*}{ Microalgae } & Phaeodactylum & Biomass & Reference & Salmo salar & Diet & $96 \%$ & $97 \%$ & $99 \%$ & $96 \%$ & $99 \%$ & 0 & [117] \\
\hline & & Biomass & Dried & Salmo salar & Diet & $96 \%$ & $97 \%$ & $98 \%$ & $96 \%$ & $99 \%$ & 30 & [117] \\
\hline & & Biomass & Dried & Salmo salar & Diet & $95 \%$ & $96 \%$ & $98 \%$ & $96 \%$ & $99 \%$ & 60 & [117] \\
\hline & & Biomass & Dried & Salmo salar & Diet & $94 \%$ & $95 \%$ & $98 \%$ & $97 \%$ & $99 \%$ & 120 & [117] \\
\hline \multirow[t]{6}{*}{ Microalgae } & Nannochloropsis & Biomass & Dried & Oreochromis niloticus & Ingred. & $50 \%$ & - & - & - & - & 300 & [15] \\
\hline & & Biomass & Pasteruised & Oreochromis niloticus & Ingred. & $56 \%$ & - & - & - & - & 300 & [15] \\
\hline & & Biomass & Freeze-dried & Oreochromis niloticus & Ingred. & $58 \%$ & - & - & - & - & 300 & [15] \\
\hline & & Biomass & Frozen/Thawed & Oreochromis niloticus & Ingred. & $53 \%$ & - & - & - & - & 300 & [15] \\
\hline & & Biomass & Bead milled & Oreochromis niloticus & Ingred. & $82 \%$ & - & - & - & - & 300 & [15] \\
\hline & & Biomass & Commercial & Oreochromis niloticus & Ingred. & $66 \%$ & - & - & - & - & 300 & [15] \\
\hline \multirow[t]{2}{*}{ Microalgae } & Nannochloropsis & Biomass & Dried & Oncorhynchus mykiss & Ingred. & $60 \%$ & $56 \%$ & $45 \%$ & $76 \%$ & $64 \%$ & 300 & [101] \\
\hline & Isochrysis & Biomass & Dried & Oncorhynchus mykiss & Ingred. & $63 \%$ & $59 \%$ & $72 \%$ & $98 \%$ & $93 \%$ & 300 & [101] \\
\hline \multirow[t]{2}{*}{ Microalgae } & Chlorella & Biomass & Whole-cell dried & Salmo salar & Ingred. & $67 \%$ & $61 \%$ & $59 \%$ & $63 \%$ & $62 \%$ & $60-300$ & [87] \\
\hline & & Biomass & Cell-ruptured & Salmo salar & Ingred. & $85 \%$ & $62 \%$ & $88 \%$ & $93 \%$ & $93 \%$ & $60-300$ & [87] \\
\hline \multirow[t]{4}{*}{ Fungal } & Yarrowia & Biomass & Whole-cell dried & Salmo salar & Diet & $95 \%$ & $87 \%$ & $97 \%$ & $96 \%$ & $94 \%$ & 100 & [84] \\
\hline & & Biomass & Whole-cell dried & Salmo salar & Diet & $94 \%$ & $81 \%$ & $97 \%$ & $96 \%$ & $90 \%$ & 200 & [84] \\
\hline & & Biomass & Whole-cell dried & Salmo salar & Diet & $91 \%$ & $77 \%$ & $96 \%$ & $93 \%$ & $89 \%$ & 300 & [84] \\
\hline & & Oil & Fishoil + Rape & Salmo salar & Diet & $96 \%$ & $90 \%$ & $97 \%$ & $96 \%$ & $96 \%$ & $73+126$ & [84] \\
\hline
\end{tabular}


For the bacterial SCP few differences were found among different aquaculture species in terms of their digestibility of similar products (Table 4). Digestibility of a Methylococcus based SCP when fed to either O. mykiss or S. salar both resulting in protein digestibilities of $88 \%$ when included as a similar inclusion level $[8,62,106]$. Some slight differences were noted in the protein digestibility of Methyophilus SCP versus Methylococcus based SCP (79-84\% vs. 82-90\% respectively) [5,62]. Despite the intrinsically higher level of digestibility of bacterial SCP, some work has been undertaken on various processing methods to improve the digestibility of these products. Lysis of bacterial cells via autolysis or hydrolysis have both been attempted, but only improvements through autolysis were reported [118]. However, other reports contest this finding [119].

Less reported has been the digestibility of biofloc products [109-111] (Table 4). Each of the biofloc products examined was produced from a different medium and system and the protein content was relatively low in each of the products (11-22\%). Two of the studies examined digestibility in the shrimp Litopenaeus vannamei and reported contrasting values of $26 \%$ and $77 \%$ protein digestibility. A third study examined digestibility in O. niloticus and reported a value of $68 \%$ (Table 4 ).

Less reported are the digestibility characteristics of the various SCO resources and most of those that are reported were microalgal SCOs with only one fungal SCO reported. For these resources it makes more sense to focus on the digestibility of the total lipid and specific fatty acids within the products. In Table 5 a summary of the studies is presented where data on lipid and fatty acid digestibility have been reported. Among the literature, most assessments were of the diet digestibility, with only a few studies reporting the ingredient digestibility of any of the SCO resources $[15,36,87,101,116]$. Despite that, it is still possible to infer important aspects of the digestibility of the different SCOs from the diet digestibility data. Most of the resources examined were dry biomasses, but several studies reported assessments of oil extracts from SCOs [34,112,113].

Studies on the application of Schizochytrium SCO products predominated the literature, with reports on their application both as a biomass and as an oil. Most of the studies reported were conducted with S. salar as a test species $[34,86,112-115]$. As an oil, the lipid digestibility was consistently high $(>90 \%)$ and it showed no poorer digestibility qualities than any of the other oils examined in comparison. As with most oil sources, the n-3 and n- 6 polyunsaturated fatty acids (PUFA) were typically highly digestible $(>93 \%)$, whereas the saturates were less digestible (71-98\%) and the monounsaturates having digestibility values in between. As a biomass, minor effects of inclusion level were observed on the lipid digestibility $[86,114]$, mainly due to a deteriorating digestibility of the saturates with increasing inclusion. Digestibility of the PUFA was not impacted by inclusion level. Notably, the digestibility of saturates from diets with the Schizochytrium SCO products was somewhat poorer than that of saturates from fishoil.

Only a single study reporting lipid digestibilities of a Cryptocodinium SCO was found [116]. In this study reporting the ingredient digestibility in O. mykiss, the lipid digestibility of the Cryptocodinium SCO biomass was very high at $98 \%$. No fatty acid digestibilities were reported.

Other microalgal SCOs with reports on their lipid digestibilities included Nannochloropsis, Chlorella, Phaeodactylum and Isochrysis $[15,36,87,101,117]$. The lipid digestibility of the different ingredients was highly variable subject to the microalgal source (range 50-98\%). Teuling et al. [15] reported substantial impact of processing of Nannochloropsis on its lipid digestibility. Similar such effects were also reported by Tibbets et al. [34] with a Chlorella biomass. In a previously mentioned study examining the use of Nannochloropsis, Phaeodactylum and Isochrysis SCPs fed to M. vison, Skrede et al. [35] found that the lipid digestibility of the three SCPs, was impacted with increasing inclusion but was worst with Nannochloropsis inclusion reducing from $98 \%$ digestible in the reference diet to $79 \%$ when included at $240 \mathrm{~g} / \mathrm{kg}$ in the diet. The effects of processing of a Nannochloropsis SCP on the digestibility of lipids (among other nutrients) were also examined by Teuling et al. [15] in O. niloticus. Generally, the lipids were poorly $(<60 \%)$ digested from the SCP biomass, although bead-milling improved this to $82 \%$. These authors also found some good relationships between lipid digestibility and the in vitro degree 
of protein hydrolysis and protein solubility of the Nannochloropsis cells, indicating that the more the cell walls are disrupted then they increased their accessibility to nutrients inside the cells.

The only study found that reported the lipid digestibility assessment of a non-microalgal SCO was that of a fungal SCO biomass of Yarrowia lipolytica by Hatlen et al. [84]. In this study the authors reported that the lipid in the diet was 91\% to 95\% digestible, when the inclusion was varied from 300 to $100 \mathrm{~g} / \mathrm{kg}$, showing a slight deterioration in total lipid digestibility with every increased level of inclusion of the SCO. This decline in digestibility of the total lipid could be seen more clearly with a greater decline in the digestibility of the saturated fatty acids ( $87 \%$ to $77 \%$ ) and a commensurate decline in the digestibility of the n-3 PUFAs (94\% to $89 \%$ ). No changes in digestibility of either the monoenes or n-6 PUFA's were noted with increasing inclusion.

\section{Utilisation and Palatability}

Utilisation of the various SCP and SCO resources by different aquaculture species in "growth studies" represents arguably the largest information source available on the application of these materials in the sector. To avoid over-complicating the story by presenting a large range of studies in different species, a focus is made here on the application of the different classes of these resources (microalgal, fungal, bacterial and bioflocs) in each of four key species groups; salmonids, shrimp, tilapias and marine-species.

\section{Microalgal Resources}

A wide range of microalgal resources have been developed in recent years as both SCP and SCO resources [78,119]. Their advantage lies firmly in that they can be reasonably efficient producers of biomass and can rely on production inputs that often do not compete with the needs of other food production systems (e.g., salt water). They are also important sources of long-chain omega-3 PUFA, and accordingly are being eagerly sought as a much-needed alternatives to fishoil use in aquaculture feeds [120]. This next section reviews a selection of studies examining the palatability and utilisation (growth) responses of microalgal SCI for key aquaculture species groups.

\subsection{Salmonids}

In salmonids, both whole-cell and processed microalgae have been used as feed ingredients $[99,115,121]$. While some microalgae have been examined principally as protein resources (SCPs), perhaps the greatest focus in recent times for salmonids has been on the supply of omega-3 (n-3) fatty acids from microalgal sources (SCOs) as alternatives to the use of fishoil. Several microalgal SCIs have been the source of substantial research and commercial development, with the most predominant being Schizochytrium as either a biomass or processed oil product.

The use of Schizochytrium limacinum biomass, principally as an SCO in diets for grow-out S. salar has been reported in several studies $[86,114,115]$. In each case, minor to no negative effect on growth performance has been observed and, in some cases, even a small positive effect has been reported. Where either positive or negative effects have been noted, they have usually been linked to minor changes in feed intake indicating at most only subtle effects on palatability. Most notable, however, has been the change in fatty acid deposition characteristics in the muscle which will be covered in later sections. Sprague et al. [121] also examined the use of a Schizochytrium SCO biomass in the diets of S. salar at up to $110 \mathrm{~g} / \mathrm{kg}$ inclusion. As with other studies, no impact on growth or feed intake was noted, although feed conversion ratio (FCR) deteriorated with increasing inclusion of the SCO in that study. However, a notable feature of the study by Sprague et al. [121] was that they also reported the levels of persistent organic pollutants (POPs) in the fish and noted that the replacement of fishoil with the Schizochytrium SCO biomass resulted in more than a 10-fold reduction in the level of POPs. The application of other thraustochytrid biomass resources has also been examined extensively over the past 20 years $[112,121]$. Carter et al. [112] compared the inclusion of a thraustochytrid/biomass in diets against the use of either canola oil or fishoil and found no impact on feed intake or performance. 
Similarly, Chang et al. [122] fed whole thraustochytrid (Aurantiochytrium sp. TC20) biomass to S. salar fingerlings to successfully replace the fishoil component in their diets.

Other than the Schizochytrium biomass studies, several studies have also examined the use of an oil extracted from Schizochytrium (Thraustichytrid) as an SCO resource [34,113]. However, only that of Miller et al. [113] has reported the impact of the Schizochytrium (Thraustichytrid) oil on growth and feed intake. These authors found that the replacement of fishoil by a Schizochytrium oil resulted in equal performance to a fishoil or palm oil control. Feed intake was also not impacted relative to either control.

In a study examining the use of Nannochloropsis, Phaeodactylum and Isochrysis SCPs fed to S. salar, Skrede et al. [35] found that inclusion of any of the three SCP $(0,60,120$ and $240 \mathrm{~g} / \mathrm{kg})$ had no negative effect on average feed intake, but that both Nannochloropsis and Isochrysis had a clear effect on protein digestibility, and Phaeodactylum less so. No growth results were reported in this digestibility study. Growth of S. salar fed Phaeodactylum as a SCP was, however, examined by Sorensen et al. [117], who also confirmed that it had a poorer protein digestibility than the reference (fishmeal). These authors also observed that when included in diets at 30 or $60 \mathrm{~g} / \mathrm{kg}$ it had no negative effect on growth or feed intake, although the level of wholebody lipids increased with increasing inclusion. However, at an inclusion of $120 \mathrm{~g} / \mathrm{kg}$ it resulted in a reduction in feed intake and growth relative to the controls. A study by Norambuena et al. [123] reported the use of the diatom Entomoneis (19\% protein, $0.4 \%$ lipid) as a minor feed ingredient $(\leq 50 \mathrm{~g} / \mathrm{kg})$ in diets for $S$. salar. No negative impact on either growth, feed intake or FCR was noted over the experimental period.

\subsection{Shrimp}

The use of microalgal SCP and SCO has been particularly active in shrimp nutrition and has been examined in a range of studies in the past decade [124-134].

The majority of the studies found to have examined microalgal SCI resources were those focusing on the application of omega-3 enriched SCO resources as a means of replacing fishoil and/or fishmeal. The earliest study found was that by Patniak et al. [124], who examined the inclusion of two different SCO sources in diets for Pacific white shrimp, one a microalgal Schizochytrium SCO meal (rich in DHA) and the other a fungal Mortierella SCO meal (rich in 20:4n-6). In this study the authors combined both SCOs into either of two diets at different inclusion levels ( $5 \mathrm{~g} / \mathrm{kg}$ up to $20 \mathrm{~g} / \mathrm{kg}$ ) and compared performance against shrimp fed a fishoil (Menhaden) control and a commercial reference diet. At the end of the 15-week study there were no significant differences among any of the treatments, although numerically the commercial reference performed the best and the fishoil control the worst. In a subsequent series of two studies, Samocha et al. [125,126] also examined the inclusion of a Schizochytrium SCO meal (rich in DHA) and a Mortierella SCO meal (rich in ARA) in Pacific white shrimp. In the first study, fishmeal free diets were supplemented with both SCOs (at up to $50 \mathrm{~g} / \mathrm{kg}$ inclusion) or fishoil (Menhaden), whilst also testing the application of some other novel protein resources. None of the SCO diets produced growth equal to that achieved with the fishoil treatment, although the inclusion of the SCO resources resulted in better growth than from shrimp fed the diets with no added LC-PUFA. In a second study, the two different SCOs were examined at various different inclusion levels (maximum of $5.2 \mathrm{~g} / \mathrm{kg}$ ). In particular, the authors were examining the response of shrimp to changes in the level of ARA (20:4n-6), with only one diet made to be relatively deficient in DHA. Ironically, all shrimp in each treatment grew well, but again those fed the fishoil control grew significantly better than any of the microalgal SCO treatments. Shrimp fed the diet deficient in DHA grew the poorest, indicating that the shrimp were more sensitive to changes in DHA level than ARA level. But that all the microalgal SCO diets grew poorer than the fishoil based control diet perhaps indicates other constraints with these resources as well. Notably, the levels of ARA and DHA in the muscle reflected those of the diet, but the level of EPA (20:5n-3) in the muscle, in most cases exceeded the levels of ARA in each treatment despite that its levels in the diet were generally lower than those of ARA. A similar Schizochytrium SCO meal was fed to Pacific white shrimp post-larvae 
by Wang et al. [129]. These authors found that inclusion of up to $60 \mathrm{~g} / \mathrm{kg}$ was well utilised by the shrimp, with best performance observed at $20 \mathrm{~g} / \mathrm{kg}$ inclusion. A similar result was reported by Allen et al. [130] who also used a Schizochytrium SCO meal was fed to Pacific white shrimp. The use of an Aurantiochytrium SCO was reported by Araujo et al. [131], who included this microalgal SCO in diets for Pacific white shrimp at a range of levels up to $10 \mathrm{~g} / \mathrm{kg}$. The authors noted an improvement in growth with increasing inclusion level of the Aurantiochytrium SCO as well as increase in the DHA content of the lipids of the shrimp muscle. Another recent study also reported the use of an Aurantiochytrium SCO as a source of n-3 fatty acids in the diet for Pacific white shrimp [132]. Similarly, these authors found that the inclusion of the microalgal SCO improved growth of the shrimp when included at $40 \mathrm{~g} / \mathrm{kg}$ in the diet, replacing about $50 \%$ of the fishoil. Additionally, with the use of the Aurantiochytrium SCO an increase in the levels of DHA in the shrimp tail muscle was observed.

In contrast to the previously detailed studies, which focus on omega-3 supplementation via a range of microalgal SCO resources, Ju et al. [127] examined the use of a defatted Haematococcus pluvialis SCP in diets fed to Pacific white shrimp. In this study the authors found that in addition to being a useful protein ingredient, that the Haematococcus SCP was also an excellent source of carotenoids. Testing inclusion levels up to $120 \mathrm{~g} / \mathrm{kg}$, the authors found that there was no growth loss, even at the highest inclusion level, despite that the diets were also formulated to be low-protein thereby increasing the sensitivity of the experiment to changes in protein quality. Additionally, there was a concomitant increase in astaxanthin content in the shrimp with every increment of the Haematococcus SCP which was also noted as an increased redness of the shrimp.

The effect of a Nannochloropsis SCP on post-larval kuruma shrimp (Marsupenaeus japonicus) performance was evaluated by Adissin et al. [133]. The SCP was included at various inclusion levels up to $70 \mathrm{~g} / \mathrm{kg}$. An oil extract from the Nannochloropsis was also evaluated at inclusion levels of 35 and $14 \mathrm{~g} / \mathrm{kg}$. Increasing inclusion of the SCP resulted in improved growth and feed utilisation performance, despite the fact that there was a concomitant decline in feed intake. In contrast, the inclusion of the oil extract had no significant impact on performance, suggesting that the benefits observed of the SCP were not due to its fatty acid contributions.

A heterogeneous microalgal SCP was tested on Pacific white shrimp by Basri et al. [134]. Predominantly comprised of Chlorella sp., but also containing Scenedesmus and Coelastrum among other microorganisms, the spray-dried green-water culture was serially included in diets at a range of levels up to $340 \mathrm{~g} / \mathrm{kg}$. However, with each inclusion level there was a decline in performance of the shrimp suggesting that this microalgal SCP was not nutritionally suitable or that the diets had not been adequately amended to accommodate the SCP. Some improvement in pigmentation of the shrimp was noted, however.

\subsection{Tilapia}

Since 2010, the number of studies on the application of microalgae SCIs in tilapia feeds has strongly increased. The various studies include those on whole-cell microalgae [102,135] and processed microalgae SCP and SCO resources [15,36]. Except for the study of Sarker et al. [36], all studies in tilapia examined the potential of microalgae as protein source. Performance comparison between different types of microalgae as SCP across the tilapia studies has been difficult due to the large variability in maximal dietary inclusion level (from 5\% to 82\%; $[135,136]$ ), pellet production (cold-pelleted versus extrusion), details on source of microalgae [137,138], feeding level (restrictive versus satiation) and type of replacement (fishmeal versus plant ingredients as control).

As with other fish, the palatability of microalgae SCP is a major determinant on growth. Hussein et al. [137] found that the replacement of corn gluten meal (CGM) by Algamaxx was dose-dependent. At low levels of replacement (25\% CGM replacement), feed intake improved but as levels of corn gluten replacement increased ( $\geq 50 \%$ CGM replacement) feed intake was significantly reduced by up to $50 \%$ of the feed intake of the control diet. The response in growth in these studies $[137,138]$ on Algamaxx followed the same pattern as feed intake. A 5\% dietary exchange of 
Chlorella vulgaris by soybean meal did not affect feed intake, but improved growth rate by $15 \%$ [136]. Sarker et al. [139] studied the dose response of the dietary substitution of $7 \%$ fishmeal by a lipid-extracted microalgal co-product of Nannochloropsis oculata. This microalgae SCP did not affect palatability but gave a $26 \%$ lower growth rate. This strong decline in growth was most likely caused by the relatively low protein and fat digestibilities (respectively 73.5 and $60.6 \%$ ) of this algae co-product. The importance of digestibility on growth was also demonstrated in a digestibility study on the impact of processing conditions on Nannochloropsis gaditana (30\% dietary inclusion; [15]). Tilapia were fed equal amounts of protein and the study still showed differences in growth rate, which clearly related to variation in the digestible protein intake induced by different protein digestibilities of the microalgal SCPs (Figure 2 [102]). Differences in daily gain between the different SCPs was almost exclusively explained by the difference in digestible protein intake.

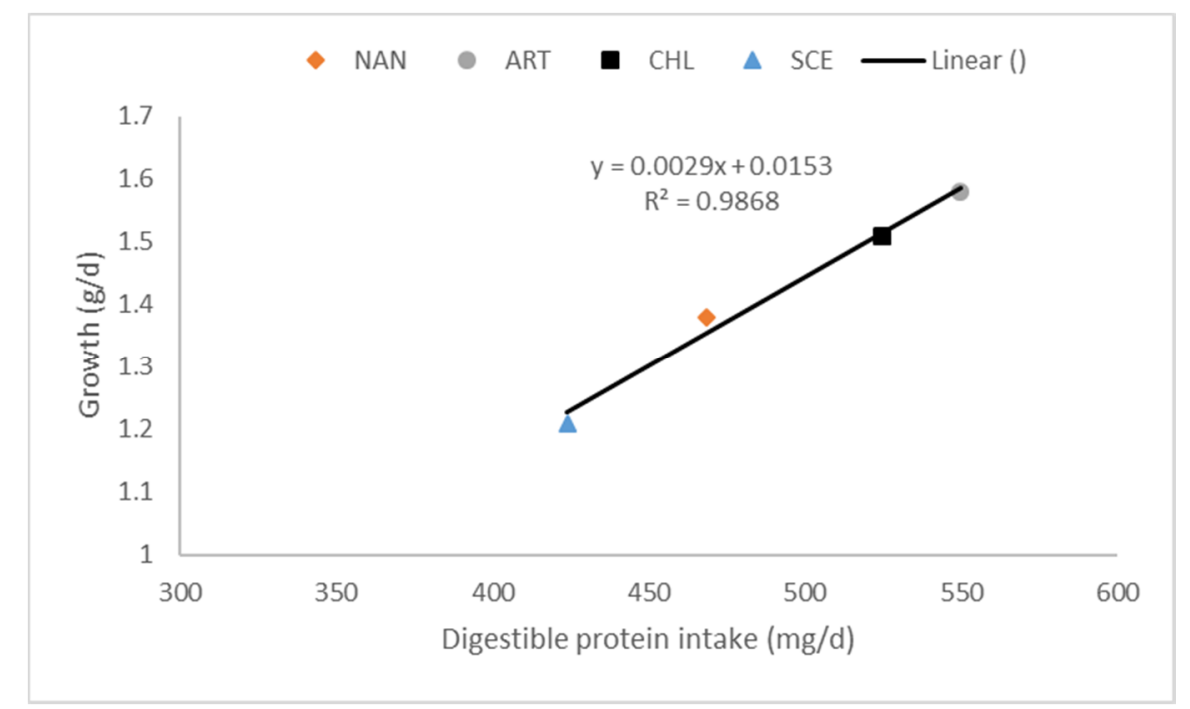

Figure 2. Relationship between digestible protein intake and growth rate in Nile tilapia fed diets containing $30 \%$ of each of various microalgal SCP resources (calculated from data published by Teuling et al. [102]) (NAN = Nannochloropsis gaditana; $\mathrm{ART}=$ Arthrospira maxima; $\mathrm{CHL}=$ Chlorella vulgaris; SCE $=$ Scenedesmus dimorphus).

Isonitrogenous and isoenergetic replacement of fishmeal by a Nannochloropsis SCP resulted in equal feed intake but led to a $9 \%$ reduction in growth. By comparison, fish fed a diet containing $80 \%$ soybean meal also had better feed intake than the microalgae diet, but growth of the soybean-fed fish was was equal [135]. In this study, the body composition of the tilapia fed with the Nannochloropsis SCP were more enriched with EPA and DHA compared to the fish fed the fishmeal diet and especially compared to the soybean diet, reflecting the differences in the levels of these fatty acids in the diets. Also, the only tilapia study on microalgae SCO [36] showed substantial shifts in EPA and DHA filet content. Isonitrogenous and isoenergetic replacement of $9 \%$ fishoil by $16.1 \%$ Schizochytrium sp. increased filet DHA content by $81 \%$ while EPA content declined by $89 \%$, which reflected the fatty acid pattern of the source of Schizochytrium sp. used. In this study the replaced of fishoil by microalgae SCO resulted in reduced feed intake by $13 \%$. Despite the lower feed intake, weight gain increased by $13 \%$ and coincided with an increase in PER from 2.4 to $3.1 \mathrm{~g} / \mathrm{g}$.

\subsection{Marine Species}

There has also been considerable application of microalgal SCP and SCO in the diets of various marine-fish species [20,140-144]. Some of the logic behind this is that many of the microalgal sources are quite rich in the important n-3 LC-PUFA that are so important for the nutrition of many marine-fish species and, as such, there has been a focus on the use of SCO resources as alternative sources of 
these n-3 LC-PUFA. Early work by Harel et al. [140] demonstrated that SCO resources made from Crypthecodinium, Chlorella, Schizochytrium and the fungus Mortierella alpina could each be used in various ways as components of either broodstock diets or larval enrichments for a range of marine fish species. Results were variable across the different fish species, with some applications showing no differences among the different SCO resources and others showing an enhanced benefit of Schizochytrium compared to Crypthecodinium.

A series of studies with European (gilthead) seabream (Sparus aurata) have shown some application of Crypthecodinium, Nannochloropsis, Phaeodactylum and Schizochytrium SCO resources in starter feeds $[20,142,144]$. In the study by Atalah et al. [20], Crypthecodinium and Phaeodactylum SCOs were included in diets at up to 39 and $48 \mathrm{~g} / \mathrm{kg}$ respectively. There were no differences in growth rate among any of the treatments in the study, although fish fed the Phaeodactylum SCO performed numerically better than fish fed either the fishoil reference or the Crypthecodinium SCO. Survival, however, was significantly better with fish fed the Crypthecodinium SCO. Ganuza et al. (2008) also explored the use of Crypthecodinium, but compared its application against Schizochytrium, another DHA producer in seabream microdiets. In a series of two trials the SCOs were used on both a whole-cell biomass basis, as well as homogenised. Inclusion of the Crypthecodinium ranged from $20 \mathrm{~g} / \mathrm{kg}$ up to $156 \mathrm{~g} / \mathrm{kg}$, where as the inclusion of the Schizochytrium ranged from $25 \mathrm{~g} / \mathrm{kg}$ to $212 \mathrm{~g} / \mathrm{kg}$. In the two trials, the first used a protein base of whole squid, whereas in the second trial the diets were based on defatted squid meal. The amounts of each SCO added were modulated slightly to balance the DHA provision in each diet. When added to microdiets based on whole squid there were no significant effects on survival or growth. However, in the second trial with the defatted squid meal none of the SCO treatments performed as well as the squid lipid reference diet. The main difference between the reference and the treatment diets was the level of EPA, which was largely deficient in the treatment diets. However, the experiment did also demonstrate that there was nominal apparent nutritional difference between the Crypthecodinium and Schizochytrium SCOs. Another study by Eryalçın et al. [142] examined the use of Crypthecodinium and Nannochloropsis SCO resources. Each SCO was examined individually (at 80 and $110 \mathrm{~g} / \mathrm{kg}$ inclusion respectively), with a third treatment examining a combination of the two. All three SCO treatments were compared against a fishoil based reference. After 34 days, fish fed the reference diet performed the best and significantly better than both treatments containing the Nannochloropsis SCO. The fish fed the diet containing the Crypthecodinium SCO meal grew poorer than the reference, but not significantly so.

Glencross and Rutherford [141] used a Crypthecodinium SCO meal (rich in DHA) and a Mortierella SCO meal (rich in ARA) in Asian seabass (Lates calcarifer) to define the requirements for DHA in that species and the impacts that supplemental EPA or ARA had on their performance. Significant impacts of the Crypthecodinium SCO meal (including at up to $113 \mathrm{~g} / \mathrm{kg}$ ) on growth were noted, although these cannot be separated from effects of DHA level. Increasing the inclusion of either SCO resource was also concomitant with an increasing redness score, which was not observed in fish fed the EPA treatment (no SCO inclusion). This redness was linked to subcutaneous haemorrhaging. While the inclusion of the Mortierella SCO (included at $75 \mathrm{~g} / \mathrm{kg}$ ) did not impact growth, the FCR was significantly poorer than that of the fishoil reference (EPA) treatment.

In European seabass (Dicentrarchus labrax) Haas et al. [143] applied SCOs produced from Pavlova and Nannochloropsis as sources of LC-PUFA. Each of the two SCO resources were included separately at two different inclusion levels into diets in replacement of the fishoil content. The Pavlova SCO resource was included at 96 and $192 \mathrm{~g} / \mathrm{kg}$. The Nannochloropsis SCO resource was included at 42 and $84 \mathrm{~g} / \mathrm{kg}$. The lower inclusion level of the Nannochloropsis SCO resource reflected its higher level $(395 \mathrm{~g} / \mathrm{kg})$ of lipid than the Pavlova SCO (196 g/kg). At the end of the growth experiment, those fish fed the diets using the Pavlova SCO grew significantly better than those fish fed the Nannochloropsis SCO resource, with both series of treatments showing a positive relationship between growth and increasing levels of either SCO resource. The poorer relative performance of the fish fed the Nannochloropsis SCO resource was mostly linked to a decline in feed intake with increasing inclusion, contrasting an increasing 
level of feed intake observed with increasing Pavlova SCO inclusion. Use of the Nannochloropsis SCO resource also reduced the level of DHA in the fish but increased the level of EPA.

A Schizochytrium SCO and an Arthrospira (Spirulina) SCP were applied to the diets of red drum (Scianops ocellatus) by Perez-Velazquez et al. [145]. Each SCI was applied to a series of six diets at increasing inclusion from 0 to $356 \mathrm{~g} / \mathrm{kg}$. The ratio of the Schizochytrium SCO and Arthrospira SCP were maintained about the same and were used in combination to progressively replace fishmeal, fishoil and soy protein concentrate. In another treatment all the fishoil was replaced by using the Schizochytrium $\mathrm{SCO}$. Over the term of the experiment there was a clear benefit to the fish from the inclusion of the two $\mathrm{SCI}$, although no significant effect was reported based on an analysis of variance (ANOVA), and use of a regression analysis would have yielded a different result. Comparison of the reference against the no-fishoil diet showed no difference, suggesting that the benefit seen in the combined inclusion of the Schizochytrium SCO and Arthrospira SCP was mostly due to the inclusion of the later resource. However, a significant decrease in the level of crude fat in the whole-body samples was noted with the use of the Schizochytrium SCO, although it also dramatically increased the whole body DHA content. This was also seen with the combined inclusion of the Schizochytrium SCO and Arthrospira SCP, which also had a higher level of DHA in the whole-body fatty acids.

\section{Fungal Resources}

Yeast is an exceptional SCP since it contains a moderate protein level, is abundant in lysine, has low toxic potential, can be cultivated on a wide range of substrates and is relatively easy to produce [146-148]. Yeast is a source of many essential B vitamins and has a balanced amino acid profile, except for sulphur-containing amino acids. Methionine is commonly supplemented into diets high in yeast $\mathrm{SCP}$, although recent studies have questioned this necessity since the requirement may be met by a blend of fish and plant protein meals, such as wheat gluten, in aqua-feeds [39,59]. This next section reviews a selection of studies examining the palatability and utilisation (growth) responses of yeast and filamentous fungi for key aquaculture species groups.

\section{Salmonids}

Work on the application of fungal SCP resources in the diets of salmonids has been an especially prolific area of research in recent years $[41,58,59,148,149]$. The use of yeast as a dietary protein for farmed fish is not a new concept, as studies have investigated this possibility since the 1970s. Species of Candida were the first yeasts to be used in diets for rainbow trout and they successfully replaced up to $40 \%$ of fishmeal $(112 \mathrm{~g} / \mathrm{kg}$ of diet) without reductions in performance, e.g., growth rate and feed efficiency $[3,150]$. Since then, studies in the early 1990 s showed that $S$. cerevisiae can replace $25 \%$ and $50 \%$ of protein $(321-500 \mathrm{~g} / \mathrm{kg}$ of diet) for rainbow trout and lake trout (Salvelinus namaycush), respectively, without reduced fish performance [104,151]. However, the main protein source in these diets was casein, which does not reflect commercial aquafeeds.

Recently, a study by Øverland et al. [58] compared the application of three different genera of yeast protein (Candida, Kluyveromyces and Saccharomyces) and found good utility from each of these SCP resources. Notably a significant improvement in palatability relative to the control diet was observed through the use of the Saccharomyces SCP. Despite each of these SCP being considered as palatable as the fishmeal-based reference diet used in the study, none of these resources delivered growth equal to fishmeal and, consequently, the FCR was also poorer for all three resources. This was consistent to some degree with the poorer digestibility of each of the resources.

In general, protein digestibility has been found to be lower for diets of $S$. cerevisiae fed to rainbow trout, Arctic charr and Atlantic salmon compared to tilapia and marine species [44,58,59]. A study on lake trout found that mechanical disruption of yeast improved growth and feed efficiency [151]. However, a study on Arctic charr found that feeding pure yeast extract, without cell walls, increased digestibility but at the expense of reduced fish growth [44]. Even in studies where digestible protein and methionine are balanced between fishmeal and yeast diets, rainbow trout 
fed higher levels of yeast have been shown to have reduced performance [59,152]. In contrast, DDGY inclusions of 112 and $180 \mathrm{~g} / \mathrm{kg}$ in diets for rainbow trout were achieved without reductions in growth performance [152,153]. However, DDGY inclusion of $223 \mathrm{~g} / \mathrm{kg}$ and higher resulted in reduced protein digestibility.

One of the main concerns about using SCP at high dietary inclusion rates is the high content of nucleic acids, e.g., DNA and RNA [154-156]. In theory, fish should be able to metabolise high concentrations of nucleic acid safely, due to higher uricase activity in the liver than other animals [104]. However, studies have found that feeding yeast to provide $100 \%$ of the protein in the diet of rainbow trout results in harmful levels of uric acid in the kidney and haemolytic anaemia in the blood [157,158]. Aside from reduced digestibility and high nucleic acid content, reduced pellet quality, and consequently reduced palatability and feed intake, may limit the use of yeast as a protein source. Studies have found that pellet quality decreases as yeast inclusion rate in the diet increases, resulting in reduced lipid absorption and increased pellet losses [152]. More research into lowering the nucleic acid content and increasing the extrusion conditions for yeast SCP diets is needed to support an increase in the inclusion and commercial use of this product in aquaculture.

Aside from being an SCP resource, some yeasts have been a source of lipids, pigments, vitamins and enzymes. Oleaginous yeasts that contain over $200 \mathrm{~g} / \mathrm{kg}$ in total lipid, such as Yarrowia lipolytica and Lipomyces starkeyi, have been genetically modified to include high levels of EPA and DHA, which have been used to replace fish and vegetable oils in diets (200 and $140 \mathrm{~g} / \mathrm{kg}$ ) for Atlantic salmon [84] and Arctic charr [159] without reductions in growth performance. Phaffia rhodozyma has been reported to be a natural source of pigment (astaxanthin), amino acids, fatty acids (e.g., 18:2n-6 and 18:3n-3), vitamins (e.g., niacin) and minerals [94]. Wickerhamomyces anomalus is capable of inhibiting moulds during feed storage and increasing phosphorus digestibility in feeds for rainbow trout due to high activity of extracellular enzymes, especially phytase [59]. In addition to DDGY and brewer's yeast, there is increasing use of organic waste streams as substrate for yeast production [146]. Some yeasts also have the capacity to inactivate pathogens, such as prions [160], which increases the potential of yeast as a biological barrier to disease transmission in the food chain.

\subsection{Shrimp}

In our review of the literature, we found that the inclusion level of yeast SCP was typically lower than that for other species, although both yeast and yeast extracts were frequently used, with most studies focusing on the Pacific white shrimp (Litopenaeus vannamei). We focused on studies that used yeast as a protein source above $10 \mathrm{~g} / \mathrm{kg}$ in the diet, although there are several reviews that focus on the use of yeast and fungal polysaccharides (beta-glucans and MOS) as a probiotics and immunostimulant for shrimp [161,162].

Several studies that fed yeast SCP to shrimp found similar or increased growth with low inclusions, while higher inclusions often resulted in reduced growth. A study by Gamboa-Delgado et al. [163] found similar growth and nitrogen retention among treatments when Pacific white shrimp were fed $255 \mathrm{~g} / \mathrm{kg}$ of Torula yeast (Candida utlilis), but higher growth when fed a lower inclusion $(127 \mathrm{~g} / \mathrm{kg}$ ). In another study, similar weight gain, FCR and survival were found among treatments when fed DDGY up to 150 and $300 \mathrm{~g} / \mathrm{kg}$ in both pond and tank systems [164,165]. For yeast extracts, similar growth, and feed utilisation among treatments has been found when shrimp were fed an inclusion of $130 \mathrm{~g} / \mathrm{kg}$, while higher diet protein digestibility was observed at $110 \mathrm{~g} / \mathrm{kg}$ inclusion [166]. However, similar to fish, FCR was improved when shrimp were fed diets with 180 and $250 \mathrm{~g} / \mathrm{kg}$ inclusion. In contrast, feeding $60 \mathrm{~g} / \mathrm{kg}$ of yeast in plant-based diets resulted in poorer growth, FCR and digestibilities of energy, protein, and amino acids [167]. The yeast ingredient had a low protein digestibility of $53 \%$ compared to $97 \%$ for soybean meal, which suggests the lack of digestibility was the main issue. In addition, the authors suggested that the yeast diet was stickier and may have reduced palatability. Despite this study, inclusion levels between 130-300 g/kg can be fed to Pacific white shrimp without reductions in growth and feed utilisation. 
At very low inclusions, yeast has been used both as a protein source and as an immunostimulant for shrimp. In a study by Xiong et al. [168], shrimp fed 30-50 g/ $\mathrm{kg}$ of nucleotide rich yeast resulted in improved growth, feed utilisation, innate immunity and intestinal morphology. In another study, feeding $50 \mathrm{~g} / \mathrm{kg}$ of brewer's yeast resulted in higher survival following a Vibrio injection at low salinity [169]. Feeding low levels of yeast to shrimp may be beneficial in partially replacing fishmeal or soy while increasing disease resistance and gut health.

In addition to Pacific white shrimp, a couple of studies have seen similar effects of yeast SCP on other shrimp species. In a study with black tiger shrimp (Penaeus monodon), they found an improved survival and immune response of shrimp fed $100 \mathrm{~g} / \mathrm{kg}$ of Candida aquaetextoris [170]. In a study with giant freshwater prawn (Macrobrachium rosenbergii), they found similar growth, FCR and protein retention in shrimp fed up to $155 \mathrm{~g} / \mathrm{kg}$ in both clear and biofloc systems, although growth and feed efficiency were reduced when fed $300 \mathrm{~g} / \mathrm{kg}$ only in the clear water system [171].

\subsection{Tilapia}

Inclusion of yeast in diets for tilapia has been more focused on improving growth, feed efficiency, gut health and disease resistance as well as providing a source of protein. This is not a review on the use of yeasts and yeast cell walls (beta-glucans and MOS) at $1-50 \mathrm{~g} / \mathrm{kg}$ of the diet as immunostimulants, prebiotics or probiotics for tilapia species, as this has been done previously [172]. This section focuses on feeding yeast as a SCP to tilapia at inclusion levels between $50-500 \mathrm{~g} / \mathrm{kg}$, mainly as a bulk source of proteins in aqua-feeds.

The majority of the research on using yeast as a SCP for tilapia diets has focused on Nile tilapia, which can tolerate higher levels of yeast in the diet compared to salmonids and shrimp. However, similar to these species there is a maximum inclusion level in tilapia feeds before we see negative effects on growth and feed utilisation. Ozório et al. [173] found similar growth and feed efficiency when Nile tilapia were fed $160 \mathrm{~g} / \mathrm{kg}$ brewer's yeast, although inclusion of 270 and $380 \mathrm{~g} / \mathrm{kg}$ resulted in reduced growth, protein and lipid retentions. Similar growth was found when tilapia were fed a mixture of yeasts Saccharomyces cerevisiae and Candida utilis grown on plant waste up to $116 \mathrm{~g} / \mathrm{kg}$, although reduced growth and higher FCR were observed when they were fed an inclusion of $348 \mathrm{~g} / \mathrm{kg}$ [174]. Faveofori et al. [175] found that growth and FCR for Nile tilapia fed up to $500 \mathrm{~g} / \mathrm{kg}$ yeast was similar, whereas only $328 \mathrm{~g} / \mathrm{kg}$ was ideal for African catfish (Clarias gariepinus). No matter the species of yeast or tilapia, the maximum inclusion rate of yeast SCP without negative effects on growth or feed utilisation seems to be between $160-500 \mathrm{~g} / \mathrm{kg}$ of the diet based on previous research.

Low inclusions of yeast may improve tilapia growth and feed utilisation by providing essential nutrients and/or stimulating the immune system from yeast-derived beta-glucans and MOS [172]. Abass et al. [176] found higher growth, feed efficiency (i.e., FCR and protein/lipid retention), stress tolerance to hypoxia and disease resistance to Aeromonas when fed up to $70 \mathrm{~g} / \mathrm{kg}$ of yeast. However, digestibility of yeast is typically not as high as fishmeal and some plant proteins, thus high inclusions of yeast usually result in poorer feed utilisation and fish growth [173]. A decrease in energy and protein digestibility was found in another study with increasing yeast level despite higher feed intake, weight gain and blood cells counts when fed $80 \mathrm{~g} / \mathrm{kg}$ of baker's yeast [177].

It is important that nutritional studies compare test diets to high-quality reference diets or else findings may be misleading. For example, a study found improved growth and FCR when Nile tilapia were fed $450 \mathrm{~g} / \mathrm{kg}$ yeast extract with supplemented lysine and methionine compared to a reference diet with no fishmeal and based almost entirely on soybean meal $(839 \mathrm{~g} / \mathrm{kg})$, although similar growth and FCR were also found compared to a reference diet of $200 \mathrm{~g} / \mathrm{kg}$ fishmeal [178]. In addition, combinations of animal and plant protein sources can improve the tolerance of feeding high-yeast SCP diets to tilapia. One study focused on Mozambique tilapia (Oreochromis mossambicus) and found a non-significant increase in growth and nitrogen retention when fed $260 \mathrm{~g} / \mathrm{kg}$ of Torula yeast (Candida utilis) with a mixture of meat and bone meal, alfalfa protein concentrate and soybean meal [179]. Conversely, this study compared the yeast-based diets to a reference diet that unusually had $640 \mathrm{~g} / \mathrm{kg}$ 
of fishmeal, which indicates that positive effects of yeast may also be masked by high inclusion of fishmeal in reference diets. Most commercial tilapia diets had on average $\sim 50 \mathrm{~g} / \mathrm{kg}$ of fishmeal [180], thus reference diets in nutritional studies should be formulated as such to ensure relevance.

Tilapia can also be raised in very different rearing systems and temperature ranges to salmonids, which should be taken into account when assessing the dietary effects of yeast. Similar growth and FCR fed up to $180 \mathrm{~g} / \mathrm{kg}$ brewer's yeast in both clear and biofloc systems, although growth was reduced at $300 \mathrm{~g} / \mathrm{kg}$ [181]. Effects of feeding $150 \mathrm{~g} / \mathrm{kg}$ of yeast Kluyveromyces marxianus on growth and muscle composition of Nile tilapia was monitored over four different seasons where they found feeding yeast only affected protein content while PUFA (e.g., EPA and DHA) did not differ compared to the control diet despite seasonal changes in PUFA levels [182].

\subsection{Marine Species}

Most of the research on yeast SCP has focused on salmonids, shrimps and tilapias, although a few studies exist that fed yeast to marine fish species. Feeding $548 \mathrm{~g} / \mathrm{kg}$ of brewer's yeast resulted in similar growth and feed efficiency while feeding a lower inclusion level $(329 \mathrm{~g} / \mathrm{kg})$, improved FCR, and protein retention for European sea bass (Dicentrarchus labrax) [183]. In addition, there was no effect of methionine supplementation in the highest yeast diet. Feeding $58 \mathrm{~g} / \mathrm{kg}$ of yeast extract and $230 \mathrm{~g} / \mathrm{kg}$ of brewer's yeast resulted in increased growth and feed intake in gilthead sea bream (Sparus aurata) [184]. For hybrid striped bass (Morone chrysops $\times$ M. saxatilis), similar weight gain, feed efficiency and survival were found when fed up to $40 \mathrm{~g} / \mathrm{kg}$ brewer's yeast, although fish had higher survival after a bath infection with Streptococcus iniae [185]. The tolerance of high inclusion levels of yeast SCP seems to depend on the marine species and more research is needed to determine acceptable feeding levels and benefits to growth performance and feed utilisation.

\section{Bacterial Resources}

In contrast to the volume of work with microalgal SCI resources, studies that deal with the specific application of bacterial resources in the feeds for aquaculture species have been relatively rare $[8,186]$. Although work began on bacterial protein production about 50 years ago (even earlier if we consider Spirulina, which has long been used as a feed ingredient [187]), the revival of these resources has attracted some attention in recent years as a de novo source of producing protein, those that are non-competing with human food production based on the production of other plant or animal resources. What we could not find, however, were any studies where bacterial resources had been used to create a viable SCO resource. There has also been some speculation on the environmental credentials of some of the methanotrophic bacterial production systems in terms of their use of greenhouse gases, although whether there is credibility to that argument or not remains another question [188]. However, these resources too are certainly progressing both in terms of becoming reliable sources of protein $[8,186]$. This next section reviews a selection of studies examining the palatability and utilisation (growth) responses of key aquaculture species groups fed bacterial SCP resources.

\subsection{Salmonids}

A range of studies has demonstrated the potential benefits and issues of different bacterial SCP on the growth and utilisation by salmonids $[3,4,62,107,189,190]$. Most of the initial studies focused on bacterial SCP used rainbow trout (O. mykiss) as a test species. From as early as the late 1970s, studies using a Pseudomonas bacterial protein at up to $450 \mathrm{~g} / \mathrm{kg}$ inclusion were reported [3]. At each inclusion level in that study, however, up to $450 \mathrm{~g} / \mathrm{kg}$ inclusion, the SCP resulted in poorer feed intake and growth than that of fish fed the commercial reference diet, but the design also used varying dietary protein levels resulting in dual variables of protein level and protein sources in the design. A subsequent study using a Methylophilus bacterial protein, and a more orthodox experimental design, was assessed in diets for rainbow trout and shown to support good growth and protein utilisation with inclusion levels as high as $350 \mathrm{~g} / \mathrm{kg}$, although levels above $210 \mathrm{~g} / \mathrm{kg}$ resulted in poorer 
feed intake [4]. Kiessling and Askbrandt [191] examined the inclusion of two different bacterial sources of SCP (Brevibacterium lactofermetum and Bacterium glutamaticum) at 0, 40, 80 and $160 \mathrm{~g} / \mathrm{kg}$ inclusion in diets balanced for digestible protein fed to rainbow trout. The Brevibacterium bacterial SCP supported equivalent growth at up the $160 \mathrm{~g} / \mathrm{kg}$ inclusion level, with feed efficiency also not impacted. The inclusion of the Bacterium SCP however, resulted in poorer performance at every inclusion level and this was exacerbated with increasing levels. Studies by Perera et al. [189] reported increased feed intake but poorer growth of rainbow trout fed diets with increasing dietary levels $(0,174,435$ and $696 \mathrm{~g} / \mathrm{kg})$ of a (undefined) bacterial SCP. At an inclusion of $174 \mathrm{~g} / \mathrm{kg}$ their growth was not significantly poorer than that of the control based on an ANOVA but based on regression it was shown to have been impacted at every inclusion level. The most recent study examining a bacterial SCP with rainbow trout was that of Aas et al. [190] who tested a Methylococcus-based SCP and an autolysate of that same bacterial SCP. No significant effects on feed intake or growth were observed in the study, but performance of the fish fed the autolysate of the bacterial SCP were numerically lower than that of both the control and the standard bacterial SCP at the same inclusion level. The study also demonstrated that initial poorer feed intake of diets with high inclusion levels $(270 \mathrm{~g} / \mathrm{kg})$ were ameliorated over time, suggesting that initial effects may be linked to palatability issues of the SCP. A recent study examined the application of an SCP produced from Methylobacterium extorquens in diets for rainbow trout [64]. The Methylobacterium SCP was included in diets at 0,50 and $100 \mathrm{~g} / \mathrm{kg}$ and used to replace soybean meal. A non-significant decline in growth was observed with increasing inclusion of the SCP, which was linked to a decline in feed intake. However, significant improvements in survival were observed with increasing inclusion level of the SCP.

More recently the focus has been more on the application of bacterial SCP in the diets of Atlantic salmon (S. salar). Storebakken et al. [106] examined the serial-inclusion of a Methylococcus based SCP in the diets of and found that when included above $99 \mathrm{~g} / \mathrm{kg}$ that there was a significant decline in weight. Despite this decline in weight, there was an increase in body lipid content similar to what was observed by Kaushik and Luquet [5], with rainbow trout. However, there was a clear adaptation of the fish to the SCP over the 12-months of the study. By the later stages of the trial the fish were able to effectively tolerate diets including up to $193 \mathrm{~g} / \mathrm{kg}$ of the Methylococcus SCP. It was not possible to determine if these effects were linked to feed intake or utilisation as no intake data were presented in the publication. A subsequent study by Berge et al. [192] evaluated the same SCP at two inclusion levels (100 and $200 \mathrm{~g} / \mathrm{kg}$ ) offsetting a high-quality fishmeal in diets fed to Atlantic salmon. Both feed intake and growth were numerically, but not significantly, lower after the 5-month study as a result of the inclusion of the bacterial SCP, with effects more pronounced at the higher inclusion level. Feed conversion was also poorer at the higher inclusion level, especially at earlier stages of the study. In contrast to other studies, the lipid levels in the carcass were lower at the higher inclusion levels of the bacterial SCP. More recently, studies with Atlantic salmon have reported improved growth rates, feed conversion and protein utilisation with Methylococcus SCP included in diets at up to $360 \mathrm{~g} / \mathrm{kg}$ [107]. This improvement in growth was independent of feed intake, which did not vary between the treatments demonstrating that the benefit was due to the inherent composition of the bacterial SCP rather than an intake mediated effect. In particular, a significant reduction in branchial + urinary nitrogen losses and maintenance energy losses was observed with increasing inclusion of the bacterial SCP. The application of a Spirulina SCP to the diets of rainbow trout has also been trialled [193]. In that study the authors found that the fish could tolerate up to $100 \mathrm{~g} / \mathrm{kg}$ inclusion of the Spirulina SCP, but levels above that were not tested. No decline in palatability at any inclusion level was noted.

\subsection{Shrimp}

Of the bacterial SCP studies reported in shrimp, most centre on the application of Spirulina [194-196]. Very few studies were found on other bacterial SCP products [197]. By contrast, there were many studies examining the application of microbial bioflocs, which include bacterial biomass, but those will be covered in a later section. There were several studies that reported the evaluation of bacterial 
fermented plant-products [198,199] but, given that the bacterial component of those is so small, they will not be considered in the context of this review.

A study by Hanel et al. [194] examined the replacement of fishmeal by a lyophylized powder of Spirulina in diets for Pacific white shrimp (L. vannamei). These authors found that by adding powdered Spirulina to a shrimp diet that they were able to significantly improve the performance of that diet to become equivalent to that of a higher-quality diet. Not only were there improvements in growth, but also pigmentation benefits were noted. Other studies have also shown benefits beyond nutrient source provision from Spirulina in shrimp. Silvia-Neto et al. [195] reported improvements in palatability when Spirulina SCP was included, whereas Machias-Sancho et al. [196] found that a small inclusion $(100 \mathrm{~g} / \mathrm{kg})$ stimulated the production of granular hemocytes in the hemolymph of the shrimp. Good growth performance was also observed in this study up to an inclusion of $300 \mathrm{~g} / \mathrm{kg}$, above which there was a significant deterioration in both growth and feed conversion.

The only study found to have examined the use of a non-Spirulina bacterial SCP with shrimp was that by Hamidoghli et al. [197], who examined the use of a Corynebacterium ammoniagenes SCP product (PROTIDE ${ }^{\mathrm{TM}}$ ). In that study the authors trialled a series of five inclusion levels from 0 to $80 \mathrm{~g} / \mathrm{kg}$ in diets fed shrimp and found that above $40 \mathrm{~g} / \mathrm{kg}$ inclusion there was a significant decline in growth, although no commensurate decline in feed intake. This suggests that the problem with the Corynebacterium SCP was not due to palatability, but rather the utilisation potential of the ingredient or the presence of some anti-nutrient.

\subsection{Tilapia}

Several studies examining the use of a Spirulina SCP have been reported with Nile tilapia (O. niloticus) [61,200]. In the study by Olvera-Novoa et al. [61], a Spirulina maxima SCP was added to diets of fry at a series of inclusion levels up to $525 \mathrm{~g} / \mathrm{kg}$. However, there was a progressive decline in growth with every inclusion level which was significant based on ANOVA at the $300 \mathrm{~g} / \mathrm{kg}$ inclusion level. The deterioration in growth was mostly driven by a deterioration in palatability with increasing Spirulina SCP inclusion. A similar study by Velasquez et al. [200], also serially evaluating the inclusion of a Spirulina SCP at up to $500 \mathrm{~g} / \mathrm{kg}$ inclusion, found a similar response with a decline in performance at the highest inclusion level, linked to poorer feed intake, but a slight improvement in growth at moderate $(190-390 \mathrm{~g} / \mathrm{kg})$ inclusion levels.

\subsection{Marine Species}

There have been relatively few studies on the application of bacterial protein resources in the diets of marine species. In addition to the suite of studies undertaken with rainbow trout and Atlantic salmon on the Methyolocuccus SCP, Aas et al. [201] also evaluated the same SCP resource in Atlantic halibut (Hippoglossus hippoglossus). Performance of the halibut was examined at either of three inclusion levels $(0,90$ and $180 \mathrm{~g} / \mathrm{kg})$. A negative impact was observed on growth and feed intake at the $180 \mathrm{~g} / \mathrm{kg}$ inclusion level, but not at the $90 \mathrm{~g} / \mathrm{kg}$ inclusion level. Of the other studies with marine fish that were identified, both examined the use of a purple phototrophic bacterial biomass when included in diets for Asian seabass, but each comprised a different bacterial species [202,203]. The earlier study by Shapawi et al. [202] examined the use of a Rhodovulum SCP at very low inclusion levels of 3,6 and $9 \mathrm{~g} / \mathrm{kg}$ and found no impact on growth or feed intake over the 12-week duration of the study. The later study, by Delamare-Deboutteville et al. [203], examined the use of a mixed culture of purple phototrophic bacterial (PPB) biomass based on Rhodopseudomonas sp. and Rhodobacter sp. In the second study, fishmeal was progressively replaced by the PPB at 0, 100, 200 and $300 \mathrm{~g} / \mathrm{kg}$ in the diet. After 7 weeks of feeding on the diets there were clear, significant effects on growth and FCR of PPB inclusion at every inclusion level based on a regression analysis of the data. The effects were not linked to palatability effects, with no significant differences in feed intake among the treatments. 


\section{Biofloc Resources}

The heterogenous mix of each of the other single-cell resources, combined with by-products from each, to produce a flocculated bio-aggregate known as a biofloc, presents a greater degree of complexity as a feed ingredient $[17,65,204]$. Although the characteristics of these SCI are highly diverse depending on the various production parameters employed, most such studies have focused on protein production utilising in situ nitrogenous inputs with added carbon inputs to fuel the microbial productivity $[66,72,73]$. Notably, several studies have also been reported where nutritional components other than protein were the focus of production [204-206]. This next section reviews a selection of these studies examining the palatability and utilisation (growth) responses of key aquaculture species groups fed these resources.

\subsection{Shrimp}

Shrimp perhaps represent the main species where biofloc SCI products have been applied with some success in the past decade $[75-77,206,207]$. Various types of harvested microbial bioflocs have been produced, including those from specific pond-based production, sequencing-batch reactors, and recirculated aquaculture systems [75,76,206,207]. Notably, the different systems have reported markedly different compositions of the protein content in the bioflocs, with a 10-fold range in levels from $\sim 50 \mathrm{~g} / \mathrm{kg}$ to $500 \mathrm{~g} / \mathrm{kg}$.

Application of a biofloc SCI in the diets of both Pacific white shrimp (L. vannamei) and black tiger shrimp (Penaeus monodon) species have shown some remarkable properties in being to be able to stimulate the growth of shrimp, in some cases by more than $50 \%[75-77,206,207]$. Early studies by Ju et al. [206] included whole and various biofloc fractions in diets fed Pacific white shrimp and found that adding an intact biofloc to the diet at $200 \mathrm{~g} / \mathrm{kg}$ improved the growth rate about $17 \%$ and that this bioactive benefit could be attributed to the acetone-soluble fraction, which was suggested to contain carotenoids, bromophenols and other phenolic compounds. Other studies examining the inclusion of bioflocs have also reported growth improvement. Kuhn et al. [75] reported an improvement in growth of Pacific white shrimp of $\sim 50 \%$ when using a high-protein $(490 \mathrm{~g} / \mathrm{kg})$ microbial biofloc produced using a sequencing-batch reactor, included at $157 \mathrm{~g} / \mathrm{kg}$ in the diet. By contrast, Glencross et al. [76,77], who used a low-protein microbial biofloc $(\sim 40 \mathrm{~g} / \mathrm{kg})$ in two separate studies at $100 \mathrm{~g} / \mathrm{kg}$ inclusion in diets fed to black tiger shrimp, reported growth improvements of $42 \%$ and $50 \%$, respectively. This consistency in performance, despite the vagaries in protein level seem to insinuate that the bioactivity is not linked to the protein content of the biofloc and reinforces to some extent the observations of Ju et al. [206].

The growth stimulation benefits reported by various groups have also been used in various practical applications to compensate for either a reduction in diet protein or the complete replacement of all marine resources (fishmeal and fishoil) in shrimp diets. In the case of compensating for a decrease of dietary protein levels from $480 \mathrm{~g} / \mathrm{kg}$ protein to $360 \mathrm{~g} / \mathrm{kg}$ protein a significant improvement in the utilisation efficiency of protein was also observed [77]. Other studies have demonstrated that it is possible to produce shrimp with no losses in growth or feed efficiency when using zero marine resource inclusion (i.e., no fishmeal or fishoil) [76,207]. In both the study by Bauer et al. [204], and the study by Glencross et al. [76], the authors noted an improvement in the FCR with increasing inclusion of the microbial biomass, this was in contrast to the study by Arnold et al. [205] where it was shown that one of the main benefits of the microbial biomass addition was that it stimulated feed intake, with no effect on FCR being observed, but significant effects on growth.

\subsection{Tilapia}

Azim and Little [208] demonstrated that Nile tilapia (O. niloticus) production was enhanced if the fish were cultured in situ with a microbial biofloc. The use of a high $(350 \mathrm{~g} / \mathrm{kg})$ or low $(240 \mathrm{~g} / \mathrm{kg})$ protein diet did not affect the composition of the biofloc produced, which had a protein content of $\sim 380 \mathrm{~g} / \mathrm{kg}$. Although produced in situ, the authors did make substantial comment about the nutritional 
quality of the biofloc as a fish food. In comparison to fish fed the same diet but without biofloc present, a $43 \%$ enhancement in growth was noted, along with a $30 \%$ improvement in FCR, indicating that there was both an increase in feed intake, as well as nutritional quality. In a second study by these authors, they focused on the production of the biofloc as a separate protein resource based on the discharge from Nile tilapia production and were able to produce a biofloc with $500 \mathrm{~g} / \mathrm{kg}$ of protein [209]. However, recent work by Simon et al. [210] demonstrated the $100 \mathrm{~g} / \mathrm{kg}$ inclusion of a microbial biofloc in the diets of Nile tilapia resulted in a significant improvement in growth $(\sim 35 \%)$ despite the fact that the microbial biofloc (Novacq ${ }^{\mathrm{TM}}$ ) material was almost devoid of protein. The authors noted that the main effect was an improvement in feed intake, with no improvements in FCR observed.

\subsection{Salmonids and Marine Species}

In contrast to all the studies examining the application of microalgal, fungal and bacterial SCP, no studies were found that had examined the application of a microbial biofloc on any salmonid or marine species. Given the interesting responses observed with other species, this is something that perhaps needs to be reconsidered.

\section{Immunological and Health Allied Assessments}

Several studies with various SCI have reported positive effects on immunological, microbiome and inflammatory responses in different species through the use of microbial products. In particular, some microbial products are known to contain relatively high levels of certain immunostimulatory molecules such as nucleotides, peptidoglycans, and $\beta$-glucans among others. As such their inclusion in feeds brings these accessory molecules in addition to the protein and lipid content of the SCI. In many cases the various microbial products have been secondarily processed to concentrate these bioactive molecules to potentiate their impact [211-214].

Several studies with microalgal products affecting the immune function have been reported. Kousoulaki et al. [114] reported improvements in goblet cell proliferation, mucus production and inducible nitric oxide synthase activity in Atlantic salmon fed a Schizochytrium SCP. Distinct effects on the microbiome of the gastrointestinal tract of rainbow trout were reported by Lyons et al. [214], with the inclusion of a Schizochytrium SCP. Although the microbiomes in both the test and control fish were similar, the diversity of the microbiome in the fish fed the Schizochytrium SCP was greater. The application of a Navicula SCP in the diet of gilthead seabream (S. aurata) was found to stimulate various innate immune and inflammation parameters [215].

Substantially more work was found on the immune response of aquaculture species, especially shrimp, fed various fungal products. This likely stems from the known presence of high levels of $\beta$-glucans and nucleotides in Saccharomyces yeast products. In most cases, however, these resources had been processed to concentrate these $\beta$-glucan fractions before they are applied at relatively low inclusion levels in feeds $[211,216]$. However, the impact of such $\beta$-glucan fractions on the immune function of black tiger shrimp as expressed by phenoloxidase activity of the haemolymph was notable [211]. Similar benefits to Pacific white shrimp when challenged with a Vibrio sp. bacterial challenge were also reported [216]. Another study, but this time using a Candida yeast product, included at $100 \mathrm{~g} / \mathrm{kg}$, fed to black tiger shrimp, before a challenge against white-spot shrimp virus, produced enhanced resistance to the virus [170]. More recently, a study with post-smolt Atlantic salmon fed a Candida yeast product found that this SCP enhanced the expression of a variety immune system parameters of the fish, whilst also reducing inflammatory processes [217].

Various impacts of a Methylococcus bacterial SCP on the reduction in intestinal inflammation in Atlantic salmon have also been reported $[212,213,218]$. This has been shown to benefit the amelioration of soybean-induced distal enteritis and a particular fraction of the resource (the cell-wall) has been implicated as conferring this benefit [212,213].

Some biofloc-based products have also been reported to have positive effects on the immune system of various species $[67,216,219,220]$. In black tiger shrimp, improvements to specific pathogen 
(gill-associated virus) resistance have been reported through the use of a biofloc-based product (Novacq ${ }^{\mathrm{TM}}$ ) [98]. Grassi et al. [219] also reported an increased antioxidant status (based on reduced levels of TBARS of the plasma) of Nile tilapia when fed various microbial biomasses (bacterial and fungal) at very low levels $(<5 \mathrm{~g} / \mathrm{kg})$. Positive effects on the immune response (phenoloxidase and respiratory burst) and disease resistance of Pacific white shrimp to infectious myonecrosis virus fed a microbial biofloc grown on different carbon sources were reported by Ekasari et al. [67]. Zhao et al. [220] also noted improvements in haemocyte count, bacteriolytic and antibacterial activity in Pacific white shrimp fed a microbial biofloc.

\section{Processing Effects (Functionality)}

There have not been many studies examining the influence of different SCI of feed-processing effects. In these types of study, research usually involves different formulations being tested in extrusion or pelleting processing systems with subsequent assessment of pellet qualities $[18,19]$. In terms of effects of inclusion into aquaculture diets, few studies have specifically reported many effects. The effects of a Schizochytrium SCP on the physical properties of an extruded salmon feed were reported by Samuelsen et al. [221]. As a high-lipid ingredient, it was suggested that there may be problems with high inclusion of Schizochytrium SCP in extruded feeds. In this study, the authors examined the inclusion of the Schizochytrium SCP in an extruded salmon formulation using a mixture-modelling approach with inclusion levels up to $222 \mathrm{~g} / \mathrm{kg}$. Generally, increasing the inclusion of the SCP reduced the specific mechanical energy, viscosity, and melt temperatures of the extrudate, which resulted in pellets produced with a lower hardness and durability. Optimal inclusion of the Schizochytrium SCP for pellet physical parameters was suggested to be around $132 \mathrm{~g} / \mathrm{kg}$. Øverland et al. [222] reported the effects of different bacterial protein sources (basic or homogenate) when included into extruded salmon diets. The authors found that the bacterial SCPs increased bulk density and hardness of the pellets but reduced the pellet durability. There were only minor differences in effects of the different sources of bacterial protein. No specific studies on the influence of fungal SCP or bioflocs on extrusion or other feed processing parameters were found.

Another aspect of processing effects that has been examined is the way that SCI are themselves processed and how this affects their inherent value. For example, the processability of different microalgal and cyanobacterial species has been assessed in terms of their cellular rupture through the bead-milling process $[15,102]$. In that study the authors found that there were marked differences among the microalgal and cyanobacterial species in their rate of release of protein following bead milling. Spirulina was easily ruptured and released its protein very quickly within $10 \mathrm{~min}$, whereas the microalgal sources of Nannochloropsis, Chlorella and Scendodesmus all took much longer, up to an hour, to achieve the same level of protein release. Examination of number of intact cells in each sample over time showed that the microalgal cells were simply much more resistant to rupture than the cyanobacterial cells. Processing of SCI often involves a drying step to enable inclusion in to extruded/pelleted feeds. Teuling et al. $[14,15]$ compared different processes to rupture Nannochloropsis cells followed by either drum drying and freeze drying. Next to the effects on nutrient digestibility, also larger contrasts were present in the content of Maillard reaction products. In the different processed Nannochloropsis biomass, which originated from the same source, substantial differences in Maillard reaction products were present; e.g., the furosine content ranged between 0.8 and $11.4 \mathrm{~g} / \mathrm{kg}$ protein and the true lysine as percentage of total lysine between $52 \%$ and $97 \%$.

\section{Product Quality Influences}

One of the primary applications of many of the SCO resources has been to fortify the flesh of target species with an increased level of n-3 LC-PUFA $[22,86,114,115]$. Consequently, there has been a proliferation of studies assessing aspects of product (flesh) quality influences when fed various SCOs. While most of the work in this area has been with Atlantic salmon, there is a spread of studies on several other aquaculture species as well. 
A series of studies by Kousoulaki et al. $[86,114,115]$ has reported benefits to flesh quality from the inclusion of a Schizochytrium SCP in feeds for Atlantic salmon. In addition to an elevated level of both EPA and DHA, improvements to various other in the flesh quality attributes, including pigmentation, reduced gaping, and the absence of melanin spots have also been observed [86,114]. Additionally, the authors found no impacts on the sensory attributes of the flesh from fish fed the Schizochytrium SCP based on the analysis of a trained sensory panel [115]. In addition to reporting enhanced levels of DHA in the flesh of Atlantic salmon fed a different Schizochytrium SCP, Sprague et al. [122] also reported a reduction in the levels of persistent organic pollutants such as polychlorinated biphenyls.

Various flesh quality responses with other microbial SCP and other aquaculture species have been reported $[195,219,223]$. Lu et al. [223] fed Nile tilapia with raw Spirulina as the sole feed input and found a series of flesh quality traits, assessed both mechanically and sensorially, had improved, making the fish more suitable for sashimi. Also using Spirulina, Teimouri et al. [193] reported improved pigmentation in rainbow trout compared to fish fed a non-pigmented control diet. An improvement in the colour of fillets of Nile tilapia when fed various microbial biomasses (bacterial and fungal), at very low levels $(<5 \mathrm{~g} / \mathrm{kg})$, was also reported by Grassi et al. [219]. This effect was concomitant with a reduced level of malonaldehyde in the fillets which was used as a measure of antioxidant status.

\section{Next Steps}

One of the clear advantages that many of the microbial SCI have over other ingredients is their non-competitive nature with utilisation of many of our planet's limited resources for their production [224]. In a future when there is likely to be increased competition among the different animal-feed sectors and needs for the human food supply, the capacity to produce new sources of nutrients, beyond those that are currently produced, is a clear imperative. Indeed, some recent assessments have suggested that it might be possible to produce a protein yield several times higher than that of soybean production using the same land footprint and direct capture of atmospheric $\mathrm{CO}_{2}$ and renewable electricity [224]. Such sustainability claims provide some indication of a new emerging priority in ingredient assessment, that of life-cycle assessment analysis and further work in this area is warranted $[225,226]$.

Among the many SCP and SCO resources that have been evaluated, it is clear that some have some clear potential for use as ingredients in aquaculture feeds $[5,8,227]$. One of the key benefits of many of the $\mathrm{SCI}$ resources is that they confer certain biological activities through various constituents they possess (e.g., $\beta$-glucans, omega-3, nucleotides, poly-hydroxybutyrate or peptidoglycans). The processing of the various SCI to increase the concentration of these molecules might also offer opportunities to produce lower-cost co-products rich in protein $[37,40]$. As such, a co-product approach to production might help reduce the overall costs of production $[7,83]$.

However, the main industrial limitation upon their use appears to remain an economic not a technical one [228]. Like all ingredients, the various microbial SCP and SCO have critical price points at where they compete [10]. This price point can be manipulated to some extent by value-adding through a concentrating process or addition of secondary points-of-value $[37,83]$. The other element to this equation, of course, is the reduction of cost of production of the various products. Therefore, another priority needs to be focused on developing methods and strategies for larger-scale and lower-cost production of the various resources using open-field systems that might be another avenue [224]. Presently, most SCP and SCO resources are produced using capital-intensive fermentation systems so as to exert greater control over the production process [5]. The production of most of these resources requires the input of various carbon and/or nitrogen resources (among other things) and efforts need to be continued to identify ways of reducing these input costs, while maintaining qualities and increasing productivity.

One of the obvious features noted through conducting this review, in following the ingredient assessment steps as advocated by Glencross [18], was that very few, if any, of the ingredients examined can presently fulfil criteria in each of the seven steps. Therefore, in progressing the development of 
any of the latest generation of novel single-cell ingredients, clearly completing the "check-list" and resolving any weaknesses identified will provide a clear path forward and help further de-risk future applications in aquafeeds. Unfortunately, because of the huge variability in raw materials, such a "check-list" needs to be followed on a case-by-case basis.

Author Contributions: All authors (B.D.G., D.H., J.W.S.) contrinuted to the writing. All authors have read and agreed to the published version of the manuscript.

Funding: This research received no external funding.

Conflicts of Interest: The authors declare no conflict of interest.

\section{References}

1. D'Mello, J.P.F. A Study of the Amino Acid Composition of Methane Utilizing Bacteria. J. Appl. Bacteriol. 1972, 35, 145-148. [CrossRef] [PubMed]

2. D'Mello, J.P.F. The use of methane-utilising bacteria as a source of protein for young chicks1. Br. Poult. Sci. 1973, 14, 291-301. [CrossRef] [PubMed]

3. Matty, A.; Smith, P. Evaluation of a yeast, a bacterium and an alga as a protein source for rainbow trout: I. Effect of protein level on growth, gross conversion efficiency and protein conversion efficiency. Aquaculture 1978, 14, 235-246. [CrossRef]

4. Kaushik, S.; Luquet, P. Influence of bacterial protein incorporation and of sulphur amino acid supplementation to such diets on growth of rainbow trout, Salmo gairdnerii Richardson. Aquaculture 1980, 19, 163-175. [CrossRef]

5. Jones, S.W.; Karpol, A.; Friedman, S.; Maru, B.T.; Tracy, B.P. Recent advances in single cell protein use as a feed ingredient in aquaculture. Curr. Opin. Biotechnol. 2020, 61, 189-197. [CrossRef]

6. Guedes, A.C.; Malcata, F.X. Nutritional value and uses of microalgae in aquaculture. Aquaculture 2012, 10, 59-78.

7. Cohen, Z.; Ratledge, C. (Eds.) Single Cell Oils: Microbial and Algal Oils, 2nd ed.; AOCS Press: Urbana, IL, USA, 2010; p. 516.

8. Øverland, M.; Tauson, A.-H.; Shearer, K.; Skrede, A. Evaluation of methane-utilising bacteria products as feed ingredients for monogastric animals. Arch. Anim. Nutr. 2010, 64, 171-189. [CrossRef]

9. Tibbetts, S.M. The Potential for 'Next-Generation', Microalgae-Based Feed Ingredients for Salmonid Aquaculture in Context of the Blue Revolution. In Microalgal Biotechnology; IntechOpen: London, UK, 2018.

10. Glencross, B.D.; Baily, J.; Berntssen, M.H.; Hardy, R.; MacKenzie, S.; Tocher, D.R. Risk assessment of the use of alternative animal and plant raw material resources in aquaculture feeds. Rev. Aquac. 2019, 12, 703-758. [CrossRef]

11. Lee, Y.-K. Microalgal mass culture systems and methods: Their limitation and potential. Environ. Biol. Fishes 2001, 13, 307-315. [CrossRef]

12. Knuckey, R.M.; Brown, M.R.; Robert, R.; Frampton, D.M. Production of microalgal concentrates by flocculation and their assessment as aquaculture feeds. Aquac. Eng. 2006, 35, 300-313. [CrossRef]

13. Huntley, M.E.; Johnson, Z.; Brown, S.L.; Sills, D.L.; Gerber, L.; Archibald, I.; Machesky, S.C.; Granados, J.; Beal, C.; Greene, C. Demonstrated large-scale production of marine microalgae for fuels and feed. Algal Res. 2015, 10, 249-265. [CrossRef]

14. Teuling, E.; Schrama, J.; Gruppen, H.; Wierenga, P.A. Characterizing emulsion properties of microalgal and cyanobacterial protein isolates. Algal Res. 2019, 39, 101471. [CrossRef]

15. Teuling, E.; Wierenga, P.A.; Agboola, J.O.; Gruppen, H.; Schrama, J. Cell wall disruption increases bioavailability of Nannochloropsis gaditana nutrients for juvenile Nile tilapia (Oreochromis niloticus). Aquaculture 2019, 499, 269-282. [CrossRef]

16. Emerenciano, M.; Gaxiola, G.; Cuzon, G. Biofloc Technology (BFT): A Review for Aquaculture Application and Animal Food Industry. In Biomass Now—Cultivation and Utilization; IntechOpen: London, UK, 2013; pp. 301-328. [CrossRef]

17. Bossier, P.; Ekasari, J. Biofloc technology application in aquaculture to support sustainable development goals. Microb. Biotechnol. 2017, 10, 1012-1016. [CrossRef] 
18. Glencross, B.D. A feed is still only as good as its ingredients-An update on the nutritional research strategies for optimal evaluation of ingredients for aquaculture feeds. Aquac. Nutr. 2020, 13, 17-34. [CrossRef]

19. Glencross, B.D.; Booth, M.; Allan, G.L. A feed is only as good as its ingredients-A review of ingredient evaluation for aquaculture feeds. Aquac. Nutr. 2007, 13, 17-34. [CrossRef]

20. Atalah, E.; Hernandez-Cruz, C.M.; Izquierdo, M.S.; Rosenlund, G.; Caballero, M.J.; Valencia, A.; Robaina, L. Two microalgae Crypthecodinium cohnii and Phaeodactylum tricornutum as alternative source of essential fatty acids in starter feeds for seabream (Sparus aurata). Aquaculture 2007, 270, 178-185. [CrossRef]

21. Popovich, C.A.; Pistonesi, M.; Hegel, P.; Constenla, D.; Bielsa, G.B.; Martín, L.A.; Damiani, M.C.; Leonardi, P.I. Unconventional alternative biofuels: Quality assessment of biodiesel and its blends from marine diatom Navicula cincta. Algal Res. 2019, 39, 101438. [CrossRef]

22. Cardona, E.; Gueguen, Y.; Magré, K.; Lorgeoux, B.; Piquemal, D.; Pierrat, F.; Noguier, F.; Saulnier, D. Bacterial community characterization of water and intestine of the shrimp Litopenaeus stylirostris in a biofloc system. BMC Microbiol. 2016, 16, 157. [CrossRef]

23. Pérez-Fuentes, J.A.; Pérez-Rostro, C.I.; Hernández-Vergara, M.P.; Monroy-Dosta, M.D.C. Variation of the bacterial composition of biofloc and the intestine of Nile tilapia Oreochromis niloticus, cultivated using biofloc technology, supplied different feed rations. Aquac. Res. 2018, 49, 3658-3668. [CrossRef]

24. Galán, B.; Santos-Merino, M.; Nogales, J.; De la Cruz, F.; García, J.L. Microbial Oils as Nutraceuticals and Animal Feeds. In Health Consequences of Microbial Interactions with Hydrocarbons, Oils, and Lipids; Goldfine, H., Ed.; Springer Nature: Cham, Switzerland, 2019; pp. 401-445.

25. Patil, V.; Reitan, K.I.; Knutsen, G.; Mortensen, L.M.; Källqvist, T.; Olsen, E.; Gislerød, H.R. Microalgae as source of polyunsaturated fatty acids for aquaculture. Plant Biol. 2005, 6, 57-65.

26. Hemaiswarya, S.; Raja, R.; Kumar, R.R.; Ganesan, V.; Anbazhagan, C. Microalgae: A sustainable feed source for aquaculture. World J. Microbiol. Biotechnol. 2010, 27, 1737-1746. [CrossRef]

27. Shah, M.R.; Lutzu, G.A.; Alam, A.; Sarker, P.; Chowdhury, M.A.K.; Parsaeimehr, A.; Liang, Y.; Daroch, M. Microalgae in aquafeeds for a sustainable aquaculture industry. Environ. Biol. Fishes 2017, 30, 197-213. [CrossRef]

28. Oren, A. A hundred years of Dunaliella research: 1905-2005. Saline Syst. 2005, 1, 2. [CrossRef]

29. Pisal, D.S.; Lele, S.S. Carotenoid production from microalga, Dunaliella salina. Indian J. Biotechnol. 2005, 4, 476-483.

30. Moomaw, W.R.; Berzin, I.; Tzachor, A. Cutting Out the Middle Fish: Marine Microalgae as the Next Sustainable Omega-3 Fatty Acids and Protein Source. Ind. Biotechnol. 2017, 13, 234-243. [CrossRef]

31. Hamilton, H.A.; Newton, R.; Auchterlonie, N.A.; Müller, D.B. Systems approach to quantify the global omega-3 fatty acid cycle. Nat. Food 2020, 1, 59-62. [CrossRef]

32. Dunstan, G.A.; Volkman, J.K.; Barrett, S.M.; Garland, C.D. Changes in the lipid composition and maximisation of the polyunsaturated fatty acid content of three microalgae grown in mass culture. Environ. Biol. Fishes 1993, 5, 71-83. [CrossRef]

33. De Swaaf, M.E.; Sijtsma, L.; Pronk, J.T. High-cell-density fed-batch cultivation of the docosahexaenoic acid producing marine alga Crypthecodinium cohnii. Biotechnol. Bioeng. 2003, 81, 666-672. [CrossRef]

34. Tibbetts, S.M.; Scaife, M.A.; Armenta, R.E. Apparent digestibility of proximate nutrients, energy and fatty acids in nutritionally-balanced diets with partial or complete replacement of dietary fish oil with microbial oil from a novel Schizochytrium sp.(T18) by juvenile Atlantic salmon (Salmo salar L.). Aquaculture 2020, 520, 735003.

35. Skrede, A.; Mydland, L.; Ahlstrøm, Ø.; Reitan, K.; Gislerød, H.; Overland, M. Evaluation of microalgae as sources of digestible nutrients for monogastric animals. J. Anim. Feed Sci. 2011, 20, 131-142. [CrossRef]

36. Sarker, P.; Kapuscinski, A.R.; Lanois, A.J.; Livesey, E.D.; Bernhard, K.P.; Coley, M.L. Towards Sustainable Aquafeeds: Complete Substitution of Fish Oil with Marine Microalga Schizochytrium sp. Improves Growth and Fatty Acid Deposition in Juvenile Nile Tilapia (Oreochromis niloticus). PLoS ONE 2016, 11, e0156684. [CrossRef] [PubMed]

37. Soto-Sierra, L.; Stoykova, P.; Nikolov, Z.L. Extraction and fractionation of microalgae-based protein products. Algal Res. 2018, 36, 175-192. [CrossRef]

38. Zhu, L.; Zhang, X.; Ji, L.; Song, X.; Kuang, C. Changes of lipid content and fatty acid composition of Schizochytrium limacinum in response to different temperatures and salinities. Process. Biochem. 2007, 42, 210-214. [CrossRef]

39. Øverland, M.; Skrede, A. Yeast derived from lignocellulosic biomass as a sustainable feed resource for use in aquaculture. J. Sci. Food Agric. 2016, 97, 733-742. [CrossRef] [PubMed] 
40. Gamboa-Delgado, J.; Marquez-Reyes, J.M. Potential of microbial-derived nutrients for aquaculture development. Rev. Aquac. 2018, 10, 224-246. [CrossRef]

41. Huyben, D.; Nyman, A.; Vidakovic, A.; Passoth, V.; Moccia, R.; Kiessling, A.; Dicksved, J.; Lundh, T. Effects of dietary inclusion of the yeasts Saccharomyces cerevisiae and Wickerhamomyces anomalus on gut microbiota of rainbow trout. Aquaculture 2017, 473, 528-537. [CrossRef]

42. Nalage, D.; Khedkar, G.; Kalyankar, A.; Sarkate, A.; Ghodke, S. Single cell proteins. In Encyclopedia of Food and Health; Caballero, B., Finglas, P., Toldrá, F., Eds.; Academic Press: Oxford, UK, 2016; Volume 4, pp. 790-794.

43. Shurson, G. Yeast and yeast derivatives in feed additives and ingredients: Sources, characteristics, animal responses, and quantification methods. Anim. Feed Sci. Technol. 2018, 235, 60-76. [CrossRef]

44. Vidakovic, A.; Langeland, M.; Sundh, H.; Sundell, K.; Olstorpe, M.; Vielma, J.; Kiessling, A.; Lundh, T. Evaluation of growth performance and intestinal barrier function in Arctic Charr (Salvelinus alpinus) fed yeast (Saccharomyces cerevisiae), fungi (Rhizopus oryzae) and blue mussel (Mytilus edulis). Aquac. Nutr. 2015, 22, 1348-1360. [CrossRef]

45. Hoseinifar, S.H.; Esteban, M.Á.; Cuesta, A.; Sun, Y.Z. Prebiotics and fish immune response: A review of current knowledge and future perspectives. Rev. Fish. Sci. Aquac. 2015, 23, 315-328. [CrossRef]

46. Skrede, A.; Berge, G.; Storebakken, T.; Herstad, O.; Aarstad, K.; Sundstøl, F. Digestibility of bacterial protein grown on natural gas in mink, pigs, chicken and Atlantic salmon. Anim. Feed Sci. Technol. 1998, 76, 103-116. [CrossRef]

47. Parsons, J.B.; Rock, C.O. Bacterial lipids: Metabolism and membrane homeostasis. Prog. Lipid Res. 2013, 52, 249-276. [CrossRef] [PubMed]

48. Garay, L.A.; Boundy-Mills, K.L.; German, J.B. Accumulation of High-Value Lipids in Single-Cell Microorganisms: A Mechanistic Approach and Future Perspectives. J. Agric. Food Chem. 2014, 62, 2709-2727. [CrossRef] [PubMed]

49. Franke, A.; Roth, O.; De Schryver, P.; Bayer, T.; Garcia-Gonzalez, L.; Künzel, S.; Bossier, P.; Miest, J.J.; Clemmesen, C. Poly- $\beta$-hydroxybutyrate administration during early life: Effects on performance, immunity and microbial community of European sea bass yolk-sac larvae. Sci. Rep. 2017, 7, 15022. [CrossRef]

50. Gouveia, L.; Choubert, G.; Pereira, N.; Santinha, J.; Empis, J.; Gomes, E. Pigmentation of gilthead seabream, Sparus aurata (L. 1875), using Chlorella vulgaris (Chlorophyta, Volvocales) microalga. Aquac. Res. 2002, 33, 987-993. [CrossRef]

51. Waldenstedt, L.; Inborr, J.; Hansson, I.; Elwinger, K. Effects of astaxanthin-rich algal meal (Haematococcus pluvalis) on growth performance, caecal campylobacter and clostridial counts and tissue astaxanthin concentration of broiler chickens. Anim. Feed Sci. Technol. 2003, 108, 119-132. [CrossRef]

52. Lewis, T.E.; Nichols, P.D.; McMeekin, T.A. The Biotechnological Potential of Thraustochytrids. Surg. Endosc. 1999, 1, 580-587. [CrossRef]

53. Gupta, A.; Singh, D.; Barrow, C.J.; Puri, M. Exploring potential use of Australian thraustochytrids for the bioconversion of glycerol to omega-3 and carotenoids production. Biochem. Eng. J. 2013, 78, 11-17. [CrossRef]

54. McGinnis, K.M.; Dempster, T.A.; Sommerfeld, M.R. Characterization of the growth and lipid content of the diatom Chaetoceros muelleri. Environ. Biol. Fishes 1997, 9, 19-24. [CrossRef]

55. Popovich, C.A.; Damiani, C.; Constenla, D.; Leonardi, P.I. Lipid quality of the diatoms Skeletonema costatum and Navicula gregaria from the South Atlantic Coast (Argentina): Evaluation of its suitability as biodiesel feedstock. Environ. Biol. Fishes 2011, 24, 1-10. [CrossRef]

56. Ponis, E.; Parisi, G.; Le Coz, J.-R.; Robert, R.; Zittelli, G.; Tredici, M. Effect of the culture system and culture technique on biochemical characteristics of Pavlova lutheri and its nutritional value for Crassostrea gigas larvae. Aquac. Nutr. 2006, 12, 322-329. [CrossRef]

57. Coutinho, P.; Rema, P.; Otero, A.; Pereira, O.; Fábregas, J. Use of biomass of the marine microalga Isochrysis galbana in the nutrition of goldfish (Carassius auratus) larvae as source of protein and vitamins. Aquac. Res. 2006, 37, 793-798. [CrossRef]

58. Øverland, M.; Karlsson, A.; Mydland, L.T.; Romarheim, O.H.; Skrede, A. Evaluation of Candida utilis, Kluyveromyces marxianus and Saccharomyces cerevisiae yeasts as protein sources in diets for Atlantic salmon (Salmo salar). Aquaculture 2013, 402, 1-7. [CrossRef]

59. Vidakovic, A.; Huyben, D.; Sundh, H.; Nyman, A.; Vielma, J.; Passoth, V.; Kiessling, A.; Lundh, T. Growth performance, nutrient digestibility and intestinal morphology of rainbow trout (Oncorhynchus mykiss) fed graded levels of the yeasts Saccharomyces cerevisiae and Wickerhamomyces anomalus. Aquac. Nutr. 2019, 26, 275-286. [CrossRef] 
60. Sakuradani, E.; Shimizu, S. Single cell oil production by Mortierella alpina. J. Biotechnol. 2009, 144, 31-36. [CrossRef] [PubMed]

61. Olvera-Novoa, M.A.; Dominguez-Cen, L.J.; Olivera-Castillo, L.; A Martinez-Palacios, C. Effect of the use of the microalga Spirulina maxima as fish meal replacement in diets for tilapia, Oreochromis mossambicus (Peters), fry. Aquac. Res. 1998, 29, 709-715. [CrossRef]

62. Storebakken, T.; Baeverfjord, G.; Skrede, A.; Olli, J.J.; Berge, G.M. Bacterial protein grown on natural gas in diets for Atlantic salmon, Salmo salar, in freshwater. Aquaculture 2004, 241, 413-425. [CrossRef]

63. Windass, J.D.; Worsey, M.J.; Pioli, E.M.; Pioli, D.; Barth, P.T.; Atherton, K.T.; Dart, E.C.; Byrom, D.; Powell, K.; Senior, P.J. Improved conversion of methanol to single-cell protein by Methylophilus methylotrophus. Nature 1980, 287, 396-401. [CrossRef]

64. Hardy, R.W.; Patro, B.; Pujol-Baxley, C.; Marx, C.J.; Feinberg, L. Partial replacement of soybean meal with Methylobacterium extorquens single-cell protein in feeds for rainbow trout (Oncorhynchus mykiss Walbaum). Aquac. Res. 2018, 49, 2218-2224. [CrossRef]

65. Schneider, O.; Sereti, V.; Machiels, M.A.; Eding, E.H.; Verreth, J.A.J. The potential of producing heterotrophic bacteria biomass on aquaculture waste. Water Res. 2006, 40, 2684-2694. [CrossRef]

66. Moss, S.M.; Pruder, G.D. Characterization of organic particles associated with rapid growth in juvenile white shrimp, Penaeus vannamei Boone, reared under intensive culture conditions. J. Exp. Mar. Biol. Ecol. 1995, 187, 175-191. [CrossRef]

67. Ekasari, J.; Azhar, M.; Surawidjaja, E.H.; Nuryati, S.; De Schryver, P.; Bossier, P. Immune response and disease resistance of shrimp fed biofloc grown on different carbon sources. Fish Shellfish. Immunol. 2014, 41, 332-339. [CrossRef] [PubMed]

68. Burford, M.A.; Thompson, P.J.; McIntosh, R.P.; Bauman, R.H.; Pearson, D.C. The contribution of flocculated material to shrimp (Litopenaeus vannamei) nutrition in a high-intensity, zero-exchange system. Aquaculture 2004, 232, 525-537. [CrossRef]

69. Avnimelech, Y. Feeding with microbial flocs by tilapia in minimal discharge bio-flocs technology ponds. Aquaculture 2007, 264, 140-147. [CrossRef]

70. Ballester, E.L.C.; Abreu, P.; Cavalli, R.O.; Emerenciano, M.; De Abreu, L. Effect of practical diets with different protein levels on the performance of Farfantepenaeus paulensis juveniles nursed in a zero exchange suspended microbial flocs intensive system. Aquac. Nutr. 2010, 16, 163-172. [CrossRef]

71. Emerenciano, M.G.C.; Ballester, E.L.C.; Cavalli, R.O. Biofloc technology application as a food source in a limited water exchange nursery system for pink shrimp Farfantepenaeus brasiliensis (Latreille, 1817). Aquac. Res. 2011, 43, 447-457. [CrossRef]

72. Avnimelech, Y. Carbon/nitrogen ratio as a control element in aquaculture systems. Aquaculture 1999, 176, 227-235. [CrossRef]

73. Crab, R.; Defoirdt, T.; Bossier, P.; Verstraete, W. Biofloc technology in aquaculture: Beneficial effects and future challenges. Aquaculture 2012, 356, 351-356. [CrossRef]

74. Tago, Y.; Aida, K. Exocellular mucopolysaccharide closely related to bacterial floc formation. Appl. Environ. Microbiol. 1977, 34, 308-314. [CrossRef]

75. Kuhn, D.D.; Boardman, G.D.; Lawrence, A.L.; Marsh, L.; Flick, G.J. Microbial floc meal as a replacement ingredient for fish meal and soybean protein in shrimp feed. Aquaculture 2009, 296, 51-57. [CrossRef]

76. Glencross, B.; Irvin, S.; Arnold, S.; Blyth, D.; Bourne, N.; Preston, N. Effective use of microbial biomass products to facilitate the complete replacement of fishery resources in diets for the black tiger shrimp, Penaeus monodon. Aquaculture 2014, 431, 12-19. [CrossRef]

77. Glencross, B.; Arnold, S.; Irvin, S. Bioactive factors in microbial biomass have the capacity to offset reductions in the level of protein in the diet of black tiger shrimp, Penaeus monodon. Aquaculture 2015, 446, 74-79. [CrossRef]

78. Yaakob, Z.; Ali, E.; Zainal, A.; Mohamad, M.; Takkriff, M.S. An overview: Biomolecules from microalgae for animal feed and aquaculture. J. Biol. Res. 2014, 21, 6. [CrossRef]

79. Ende, S.S.; Noke, A. Heterotrophic microalgae production on food waste and by-products. J. Appl. Phycol. 2019, 31, 1565-1571. [CrossRef]

80. Sharma, S.; Hansen, L.D.; Hansen, J.Ø.; Mydland, L.T.; Horn, S.J.; Øverland, M.; Eijsink, V.G.H.; Vuoristo, K.S. Microbial Protein Produced from Brown Seaweed and Spruce Wood as a Feed Ingredient. J. Agric. Food Chem. 2018, 66, 8328-8335. [CrossRef] [PubMed] 
81. Brown, M.R.; Garland, C.D.; Jeffrey, S.W.; Jameson, I.D.; Leroi, J.M. The gross and amino acid compositions of batch and semi-continuous cultures of Isochrysis sp. (clone T. ISO), Pavlova lutheri and Nannochloropsis oculata. J. Appl. Phycol. 1993, 5, 285-296. [CrossRef]

82. Huerlimann, R.; De Nys, R.; Heimann, K. Growth, lipid content, productivity, and fatty acid composition of tropical microalgae for scale-up production. Biotechnol. Bioeng. 2010, 107, 245-257. [CrossRef]

83. Chua, E.T.; Schenk, P.M. A biorefinery for Nannochloropsis: Induction, harvesting, and extraction of EPA-rich oil and high-value protein. Bioresour. Technol. 2017, 244, 1416-1424. [CrossRef]

84. Hatlen, B.; Berge, G.M.; Odom, J.M.; Mundheim, H.; Ruyter, B. Growth performance, feed utilisation and fatty acid deposition in Atlantic salmon, Salmo salar L.; fed graded levels of high-lipid/high-EPA Yarrowia lipolytica biomass. Aquaculture 2012, 364, 39-47. [CrossRef]

85. Xie, D.; Jackson, E.N.; Zhu, Q. Sustainable source of omega-3 eicosapentaenoic acid from metabolically engineered Yarrowia lipolytica: From fundamental research to commercial production. Appl. Microbiol. Biotechnol. 2015, 99, 1599-1610. [CrossRef]

86. Katerina, K.; Mørkøre, T.; Nengas, I.; Berge, R.; Sweetman, J. Microalgae and organic minerals enhance lipid retention efficiency and fillet quality in Atlantic salmon (Salmo salar L.). Aquaculture 2016, 451, 47-57. [CrossRef]

87. Tibbetts, S.M.; Yasumaru, F.; Lemos, D. In vitro prediction of digestible protein content of marine microalgae (Nannochloropsis granulata) meals for Pacific white shrimp (Litopenaeus vannamei) and rainbow trout (Oncorhynchus mykiss). Algal Res. 2017, 21, 76-80. [CrossRef]

88. Renaud, S.M.; Thinh, L.-V.; Parry, D.L. The gross chemical composition and fatty acid composition of 18 species of tropical Australian microalgae for possible use in mariculture. Aquaculture 1999, 170, 147-159. [CrossRef]

89. Yokochi, T.; Honda, D.; Higashihara, T.; Nakahara, T. Optimization of docosahexaenoic acid production by Schizochytrium limacinum SR21. Appl. Microbiol. Biotechnol. 1998, 49, 72-76. [CrossRef]

90. Ghosh, A.; Khanra, S.; Mondal, M.; Halder, G.; Tiwari, O.; Saini, S.; Bhowmick, T.K.; Gayen, K. Progress toward isolation of strains and genetically engineered strains of microalgae for production of biofuel and other value added chemicals: A review. Energy Convers. Manag. 2016, 113, 104-118. [CrossRef]

91. Camacho-Rodríguez, J.; Macías-Sánchez, M.D.; Cerón-García, M.; Alarcón, F.J.; Molina-Grima, E. Microalgae as a potential ingredient for partial fish meal replacement in aquafeeds: Nutrient stability under different storage conditions. Environ. Biol. Fishes 2017, 30, 1049-1059. [CrossRef]

92. Lorenz, R.; Cysewski, G.R. Commercial potential for Haematococcus microalgae as a natural source of astaxanthin. Trends Biotechnol. 2000, 18, 160-167. [CrossRef]

93. Shah, M.R.; Liang, Y.; Cheng, J.J.; Daroch, M. Astaxanthin-Producing Green Microalga Haematococcus pluvialis: From Single Cell to High Value Commercial Products. Front. Plant Sci. 2016, 7, 300. [CrossRef]

94. Sanderson, G.W.; Jolly, S.O. The value of Phaffia yeast as a feed ingredient for salmonid fish. Aquaculture 1994, 124, 193-200. [CrossRef]

95. Li, P.; Gatlin, D.M. Nucleotide nutrition in fish: Current knowledge and future applications. Aquaculture 2006, 251, 141-152. [CrossRef]

96. Casadei, E.; Bird, S.; Vecino, J.L.G.; Wadsworth, S.; Secombes, C.J. The effect of peptidoglycan enriched diets on antimicrobial peptide gene expression in rainbow trout (Oncorhynchus mykiss). Fish Shellfish. Immunol. 2013, 34, 529-537. [CrossRef] [PubMed]

97. Casadei, E.; Bird, S.; Wadsworth, S.; Vecino, J.L.G.; Secombes, C.J. The longevity of the antimicrobial response in rainbow trout (Oncorhynchus mykiss) fed a peptidoglycan (PG) supplemented diet. Fish Shellfish. Immunol. 2015, 44, 316-320. [CrossRef] [PubMed]

98. Sellars, M.; Rao, M.; Polymeris, N.; Irvin, S.J.; Cowley, J.A.; Preston, N.P.; Glencross, B.D. Feed Containing Novacq Improves Resilience of Black Tiger Shrimp, Penaeus Monodon, to Gill-associated Virus-induced Mortality. J. World Aquac. Soc. 2015, 46, 328-336. [CrossRef]

99. Gong, Y.; Guterres, H.; Huntley, M.; Sørensen, M.; Kiron, V. Digestibility of the defatted microalgae Nannochloropsis sp. and Desmodesmus sp. when fed to Atlantic salmon, Salmo salar. Aquac. Nutr. 2017, 24, 56-64. [CrossRef]

100. Raji, A.A.; Jimoh, W.A.; Abu Bakar, N.H.; Taufek, N.H.M.; Muin, H.; Alias, Z.; Milow, P.; Razak, S.A. Dietary use of Spirulina (Arthrospira) and Chlorella instead of fish meal on growth and digestibility of nutrients, amino acids and fatty acids by African catfish. Environ. Biol. Fishes 2020, 1-8. [CrossRef] 
101. Sarker, P.K.; Kapuscinski, A.R.; Vandenberg, G.W.; Proulx, E.; Sitek, A.J. Towards sustainable and ocean-friendly aquafeeds: Evaluating a fish-free feed for rainbow trout (Oncorhynchus mykiss) using three marine microalgae species. Elem. Sci. Anth. 2020, 8. [CrossRef]

102. Teuling, E.; Schrama, J.; Gruppen, H.; Wierenga, P.A. Effect of cell wall characteristics on algae nutrient digestibility in Nile tilapia (Oreochromis niloticus) and African catfish (Clarus gariepinus). Aquaculture 2017, 479, 490-500. [CrossRef]

103. Agboola, J.O.; Teuling, E.; Wierenga, P.A.; Gruppen, H.; Schrama, J. Cell wall disruption: An effective strategy to improve the nutritive quality of microalgae in African catfish (Clarias gariepinus). Aquac. Nutr. 2019, 25, 783-797. [CrossRef]

104. Rumsey, G.; Kinsella, J.; Shetty, K.; Hughes, S. Effect of high dietary concentrations of brewer's dried yeast on growth performance and liver uricase in rainbow trout (Oncorhynchus mykiss). Anim. Feed Sci. Technol. 1991, 33, 177-183. [CrossRef]

105. Langeland, M.; Vidakovic, A.; Vielma, J.; Lindberg, J.E.; Kiessling, A.; Lundh, T. Digestibility of microbial and mussel meal for Arctic charr (Salvelinus alpinus) and Eurasian perch (Perca fluviatilis). Aquac. Nutr. 2016, 22, 485-495. [CrossRef]

106. Storebakken, T.; Kvien, I.; Shearer, K.; Grisdale-Helland, B.; Helland, S.; Berge, G. The apparent digestibility of diets containing fish meal, soybean meal or bacterial meal fed to Atlantic salmon (Salmo salar): Evaluation of different faecal collection methods. Aquaculture 1998, 169, 195-210. [CrossRef]

107. Aas, T.S.; Grisdale-Helland, B.; Terjesen, B.F.; Helland, S.J. Improved growth and nutrient utilisation in Atlantic salmon (Salmo salar) fed diets containing a bacterial protein meal. Aquaculture 2006, 259, 365-376. [CrossRef]

108. Øverland, M.; Romarheim, O.H.; Hovin, M.; Storebakken, T.; Skrede, A. Apparent total tract digestibility of unprocessed and extruded diets containing basic and autolyzed bacterial protein meal grown on natural gas in mink and rainbow trout. Anim. Feed Sci. Technol. 2006, 129, 237-251.

109. Ekasari, J.; Suprayudi, M.A.; Elas, P.; Senja, R.K. The digestibility of biofloc meal from African catfish culture medium as a feed raw material for Pacific white shrimp. J. Akuakultur Indones. 2019, 18, 1-8. [CrossRef]

110. Neto, H.S.; Santaella, S.T.; Nunes, A.J.P. Bioavailability of crude protein and lipid from biofloc meals produced in an activated sludge system for white shrimp, Litopenaeus vannamei. Rev. Bras. de Zootec. 2015, 44, 269-275. [CrossRef]

111. Liu, W.; Luo, G.; Tan, H.; Sun, D. Effects of sludge retention time on water quality and bioflocs yield, nutritional composition, apparent digestibility coefficients treating recirculating aquaculture system effluent in sequencing batch reactor. Aquac. Eng. 2016, 72, 58-64. [CrossRef]

112. Carter, C.G.; Bransden, M.P.; Lewis, T.E.; Nichols, P.D. Potential of thraustochytrids to partially replace fish oil in Atlantic salmon feeds. Mar. Biotechnol. 2003, 5, 480-492. [CrossRef]

113. Miller, M.; Nichols, P.D.; Carter, C.G. Replacement of fish oil with thraustochytrid Schizochytrium sp. L oil in Atlantic salmon parr (Salmo salar L.) diets. Comp. Biochem. Physiol. Part A Mol. Integr. Physiol. 2007, 148, 382-392. [CrossRef] [PubMed]

114. Katerina, K.; Østbye, T.-K.K.; Krasnov, A.; Torgersen, J.S.; Mørkøre, T.; Sweetman, J. Metabolism, health and fillet nutritional quality in Atlantic salmon (Salmo salar) fed diets containing n-3-rich microalgae. J. Nutr. Sci. 2015, 4. [CrossRef]

115. Katerina, K.; Berge, G.M.; Turid, M.; Aleksei, K.; Grete, B.; Trine, Y.; Mats, C.; John, S.; Bente, R. Microalgal Schizochytrium limacinum Biomass Improves Growth and Filet Quality When Used Long-Term as a Replacement for Fish Oil, in Modern Salmon Diets. Front. Mar. Sci. 2020, 7, 57. [CrossRef]

116. Betiku, O.C.; Barrows, F.T.; Ross, C.; Sealey, W.M. The effect of total replacement of fish oil with DHA-Gold ${ }^{\circledR}$ and plant oils on growth and fillet quality of rainbow trout (Oncorhynchus mykiss) fed a plant-based diet. Aquac. Nutr. 2016, 22, 158-169. [CrossRef]

117. Sørensen, M.; Berge, G.M.; Reitan, K.I.; Ruyter, B. Microalga Phaeodactylum tricornutum in feed for Atlantic salmon (Salmo salar)—Effect on nutrient digestibility, growth and utilization of feed. Aquaculture 2016, 460, 116-123. [CrossRef]

118. Schøyen, H.F.; Frøyland, J.R.K.; Sahlström, S.; Knutsen, S.H.; Skrede, A. Effects of autolysis and hydrolysis of bacterial protein meal grown on natural gas on chemical characterization and amino acid digestibility. Aquaculture 2005, 248, 27-33. [CrossRef] 
119. Yarnold, J.; Karan, H.; Oey, M.; Hankamer, B. Microalgal Aquafeeds As Part of a Circular Bioeconomy. Trends Plant Sci. 2019, 24, 959-970. [CrossRef] [PubMed]

120. Turchini, G.; Torstensen, B.E.; Ng, W.-K. Fish oil replacement in finfish nutrition. Rev. Aquac. 2009, 1, 10-57. [CrossRef]

121. Sprague, M.; Walton, J.; Campbell, P.; Strachan, F.; Dick, J.; Bell, J. Replacement of fish oil with a DHA-rich algal meal derived from Schizochytrium sp. on the fatty acid and persistent organic pollutant levels in diets and flesh of Atlantic salmon (Salmo salar, L.) post-smolts. Food Chem. 2015, 185, 413-421. [CrossRef]

122. Chang, K.J.; Parrish, C.C.; Simon, C.J.; Revill, A.T.; Nichols, P.D. Feeding Whole Thraustochytrid Biomass to Cultured Atlantic Salmon (Salmo salar) Fingerlings: Culture Performance and Fatty Acid Incorporation. J. Mar. Sci. Eng. 2020, 8, 207. [CrossRef]

123. Norambuena, F.; Hermon, K.; Skrzypczyk, V.; Emery, J.A.; Sharon, Y.; Beard, A.; Turchini, G. Algae in Fish Feed: Performances and Fatty Acid Metabolism in Juvenile Atlantic Salmon. PLoS ONE 2015, 10, e0124042. [CrossRef]

124. Patnaik, S.; Samocha, T.M.; Davis, D.; Bullis, R.; Browdy, C. The use of HUFA-rich algal meals in diets for Litopenaeus vannamei. Aquac. Nutr. 2006, 12, 395-401. [CrossRef]

125. Samocha, T.; Patnaik, S.; Davis, D.A.; Bullis, R.A.; Browdy, C.L. Use of commercial fermentation products as a highly unsaturated fatty acid source in practical diets for the Pacific white shrimp Litopenaeus vannamei. Aquac. Res. 2009, 41, 961-967. [CrossRef]

126. Samocha, T.; Davis, D.; Roy, L.; Carpenter, B.; Bullis, R. The effect of non-marine HUFA supplementation with fish oil removal on growth and survival of the Pacific white shrimp, Litopenaeus vannamei. Aquac. Nutr. 2010, 17, 518-525. [CrossRef]

127. Ju, Z.Y.; Deng, D.F.; Dominy, W. A defatted microalgae (Haematococcus pluvialis) meal as a protein ingredient to partially replace fishmeal in diets of Pacific white shrimp (Litopenaeus vannamei, Boone, 1931). Aquaculture 2012, 354, 50-55. [CrossRef]

128. Hende, S.V.D.; Claessens, L.; De Muylder, E.; Boon, N.; Vervaeren, H. Microalgal bacterial flocs originating from aquaculture wastewater treatment as diet ingredient for Litopenaeus vannamei (Boone). Aquac. Res. 2014, 47, 1075-1089. [CrossRef]

129. Wang, Y.; Li, M.; Filer, K.; Xue, Y.; Ai, Q.; Mai, K. Evaluation of Schizochytrium meal in microdiets of Pacific white shrimp (Litopenaeus vannamei) larvae. Aquac. Res. 2016, 48, 2328-2336. [CrossRef]

130. Allen, K.M.; Habte-Tsion, H.M.; Thompson, K.R.; Filer, K.; Tidwell, J.H.; Kumar, V. Freshwater microalgae (Schizochytrium sp.) as a substitute to fish oil for shrimp feed. Sci. Rep. 2019, 9, 1-10. [CrossRef] [PubMed]

131. Araújo, B.C.; Mata-Sotres, J.A.; Viana, M.T.; Tinajero, A.; Braga, A. Fish oil-free diets for Pacific white shrimp Litopenaeus vannamei: The effects of DHA-EPA supplementation on juvenile growth performance and muscle fatty acid profile. Aquaculture 2019, 511, 734276. [CrossRef]

132. Guimarães, A.M.; Schleder, D.D.; Nagata, M.; Nóbrega, R.O.; Fracalossi, D.M.; Seiffert, W.Q.; Vieira, F.D.N. Aurantiochytrium sp. meal can replace fish oil in practical diets for the juvenile Pacific white shrimp. Aquac. Nutr. 2019, 25, 798-807. [CrossRef]

133. Adissin, O.; Manabu, I.; Shunsuke, K.; Saichiro, Y.; Moss, A.S.; Dossou, S. Effects of dietary Nannochloropsis sp. powder and lipids on the growth performance and fatty acid composition of larval and postlarval kuruma shrimp, Marsupenaeus japonicus. Aquac. Nutr. 2019, 26, 186-200. [CrossRef]

134. Basri, N.A.; Shaleh, S.R.M.; Matanjun, P.; Noor, N.M.; Shapawi, R. The potential of microalgae meal as an ingredient in the diets of early juvenile Pacific white shrimp, Litopenaeus vannamei. Environ. Biol. Fishes 2014, 27, 857-863. [CrossRef]

135. Gbadamosi, O.; Lupatsch, I. Effects of dietary Nannochloropsis salina on the nutritional performance and fatty acid profile of Nile tilapia, Oreochromis niloticus. Algal Res. 2018, 33, 48-54. [CrossRef]

136. Mahmoud, E.; El-Sayed, B.; Mahsoub, Y.; El-Murr, A.; Neamat-Allah, A. Effect of Chlorella vulgaris enriched diet on growth performance, hemato-immunological responses, antioxidant and transcriptomics profile disorders caused by deltamethrin toxicity in Nile tilapia (Oreochromis niloticus). Fish Shellfish Immunol. 2020, 102, 422-429. [CrossRef] [PubMed]

137. Hussein, E.E.-S.; Dabrowski, K.; Lee, B.-J.; El-Saidy, D.M.S.D. Enhancing the growth of Nile tilapia larvae/juveniles by replacing plant (gluten) protein with algae protein. Aquac. Res. 2012, 44, 937-949. [CrossRef] 
138. Hussein, E.E.; Dabrowski, K.; El-Saidy, D.M.S.D.; Lee, B. Effect of dietary phosphorus supplementation on utiization of algae in the grow-out diet of Nile tilapia Oreochromis niloticus. Aquac. Res. 2014, 45, 1533-1544. [CrossRef]

139. Sarker, P.; Kapuscinski, A.R.; Bae, A.Y.; Donaldson, E.; Sitek, A.J.; Fitzgerald, D.S.; Edelson, O.F. Towards sustainable aquafeeds: Evaluating substitution of fishmeal with lipid-extracted microalgal co-product (Nannochloropsis oculata) in diets of juvenile Nile tilapia (Oreochromis niloticus). PLoS ONE 2018, 13, e0201315. [CrossRef]

140. Harel, M.; Koven, W.; Lein, I.; Bar, Y.; Behrens, P.; Stubblefield, J.; Zohar, Y.; Place, A.R. Advanced DHA, EPA and ArA enrichment materials for marine aquaculture using single cell heterotrophs. Aquaculture 2002, 213, 347-362. [CrossRef]

141. Glencross, B.; Rutherford, N. A determination of the quantitative requirements for docosahexaenoic acid for juvenile barramundi (Lates calcarifer). Aquac. Nutr. 2010, 17, e536-e548. [CrossRef]

142. Eryalçın, K.M.; Roo, J.; Saleh, R.; Atalah, E.; Benítez, T.; Betancor, M.; Hernandez-Cruz, M.D.C.; Izquierdo, M.S.; Eryalçın, K.M.; Hernandez-Cruz, M.C. Fish oil replacement by different microalgal products in microdiets for early weaning of gilthead sea bream (Sparus aurata, L.). Aquac. Res. 2012, 44, 819-828. [CrossRef]

143. Haas, S.; Bauer, J.L.; Adakli, A.; Meyer, S.; Lippemeier, S.; Schwarz, K.; Schulz, C. Marine microalgae Pavlova viridis and Nannochloropsis sp. as n-3 PUFA source in diets for juvenile European sea bass (Dicentrarchus labrax L.). Environ. Biol. Fishes 2015, 28, 1011-1021. [CrossRef]

144. Ganuza, E.; Benítez-Santana, T.; Atalah, E.; Vega-Orellana, O.M.; Ganga, R.; Izquierdo, M.S. Crypthecodinium cohnii and Schizochytrium sp. as potential substitutes to fisheries-derived oils from seabream (Sparus aurata) microdiets. Aquaculture 2008, 277, 109-116. [CrossRef]

145. Perez-Velazquez, M.; Gatlin, D.; González-Félix, M.L.; Garcia-Ortega, A. Partial replacement of fishmeal and fish oil by algal meals in diets of red drum Sciaenops ocellatus. Aquaculture 2018, 487, 41-50. [CrossRef]

146. Nasseri, A.; Rasoul-Ami, S.; Morowvat, M.H.; Ghasemi, Y. Single Cell Protein: Production and Process. Am. J. Food Technol. 2011, 6, 103-116. [CrossRef]

147. Ravindra, P. Value-added food: Single cell protein. Biotechnol. Adv. 2000, 18, 459-479.

148. Huyben, D.; Vidakovic, A.; Nyman, A.; Langeland, M.; Lundh, T.; Kiessling, A. Effects of dietary yeast inclusion and acute stress on post-prandial whole blood profiles of dorsal aorta-cannulated rainbow trout. Fish Physiol. Biochem. 2016, 43, 421-434. [CrossRef] [PubMed]

149. Huyben, D.; Sun, L.; Moccia, R.; Kiessling, A.; Dicksved, J.; Lundh, T. Dietary live yeast and increased water temperature influence the gut microbiota of rainbow trout. J. Appl. Microbiol. 2018, 124, 1377-1392. [CrossRef] [PubMed]

150. Mahnken, C.V.; Spinelli, J.; Waknitz, F. Evaluation of an alkane yeast (Candida sp.) as a substitute for fish meal in Oregon Moist Pellet: Feeding trials with coho salmon (Oncorhynchus kisutch) and rainbow trout (Salmo gairdneri). Aquaculture 1980, 20, 41-56. [CrossRef]

151. Rumsey, G.L.; Hughes, S.G.; Kinsella, J.L. Use of dietary yeast Saccharomyces cerevisiae nitrogen by lake trout. J. World Aquac. Soc. 1990, 21, 205-209. [CrossRef]

152. Hauptman, B.S.; Barrows, F.T.; Block, S.S.; Gaylord, T.G.; Paterson, J.A.; Rawles, S.D.; Sealey, W.M. Evaluation of grain distillers dried yeast as a fish meal substitute in practical-type diets of juvenile rainbow trout, Oncorhynchus mykiss. Aquaculture 2014, 432, 7-14. [CrossRef]

153. Sealey, W.M.; O’Neill, T.J.; Peach, J.T.; Gaylord, G.; Barrows, F.T.; Block, S.S. Refining Inclusion Levels of Grain Distiller's Dried Yeast in Commercial-type and Plant-based Diets for Juvenile Rainbow Trout, Oncorhynchus mykiss. J. World Aquac. Soc. 2015, 46, 434-444. [CrossRef]

154. Fox, I.H. Metabolic basis for disorders of purine nucleotide degradation. Metabolism 1981, 30, 616-634. [CrossRef]

155. Clifford, A.J.; Story, D.L. Levels of purines in foods and their metabolic effects in rats. J. Nutr. 1976, 106, 435-442. [CrossRef]

156. Waslien, C.I.; Calloway, D.H.; Margen, S.; Costa, F. Uric acid levels in men fed algae and yeast as protein sources. J. Food Sci. 1970, 35, 294-298. [CrossRef]

157. Sánchez-Muniz, F.J.; de La Higuera, M.; Varela, G. Alterations of erythrocytes of the rainbow trout (Salmo gairdneri) by the use of Hansenula anomala yeast as sole protein source. Comp. Biochem. Physiol. Part A Physiol. 1982, 72, 693-696. 
158. Huyben, D.; Vidakovic, A.; Langeland, M.; Nyman, A.; Lundh, T.; Kiessling, A. Effects of dietary yeast inclusion and acute stress on postprandial plasma free amino acid profiles of dorsal aorta-cannulated rainbow trout. Aquac. Nutr. 2017, 24, 236-246. [CrossRef]

159. Blomqvist, J.; Pickova, J.; Tilami, S.K.; Sampels, S.; Mikkelsen, N.; Brandenburg, J.; Sandgren, M.; Passoth, V. Oleaginous yeast as a component in fish feed. Sci. Rep. 2018, 8, 15945. [CrossRef] [PubMed]

160. Huyben, D.; Boqvist, S.; Passoth, V.; Renström, L.; Bengtsson, U.A.; Andréoletti, O.; Kiessling, A.; Lundh, T.; Vågsholm, I. Screening of intact yeasts and cell extracts to reduce Scrapie prions during biotransformation of food waste. Acta Veter Scand. 2018, 60, 9. [CrossRef] [PubMed]

161. Hoseinifar, S.H.; Sun, Y.-Z.; Wang, A.; Zhou, Z. Probiotics as Means of Diseases Control in Aquaculture, a Review of Current Knowledge and Future Perspectives. Front. Microbiol. 2018, 9, 2429. [CrossRef]

162. Mohan, K.; Ravichandran, S.; Muralisankar, T.; Uthayakumar, V.; Chandirasekar, R.; Seedevi, P.; Rajan, D.K. Potential uses of fungal polysaccharides as immunostimulants in fish and shrimp aquaculture: A review. Aquaculture 2019, 500, 250-263. [CrossRef]

163. Gamboa-Delgado, J.; Fernández-Díaz, B.; Nieto-López, M.G.; Cruz-Suárez, L.E. Nutritional contribution of torula yeast and fish meal to the growth of shrimp Litopenaeus vannamei as indicated by natural nitrogen stable isotopes. Aquaculture 2016, 453, 116-121. [CrossRef]

164. Achupallas, J.; Zhou, Y.; Davis, D.A. Pond production of Pacific white shrimp, Litopenaeus vannamei, fed grain distillers dried yeast. Aquac. Nutr. 2015, 22, 1222-1229. [CrossRef]

165. Achupallas, J.M.; Zhou, Y.; Davis, D.A. Use of Grain Distillers Dried Yeast in Practical Diets for Juvenile Pacific White Shrimp, Litopenaeus vannamei. J. World Aquac. Soc. 2016, 47, 220-229. [CrossRef]

166. Zhao, L.; Wang, W.; Huang, X.; Guo, T.; Wen, W.; Feng, L.; Wei, L. The effect of replacement of fish meal by yeast extract on the digestibility, growth and muscle composition of the shrimp Litopenaeus vannamei. Aquac. Res. 2017, 48, 311-320. [CrossRef]

167. Qiu, X.; Davis, D.A. Evaluation of flash dried yeast as a nutritional supplement in plant-based practical diets for Pacific white shrimp Litopenaeus vannamei. Aquac. Nutr. 2017, 23, 1244-1253. [CrossRef]

168. Xiong, J.; Jin, M.; Yuan, Y.; Luo, J.-X.; Lu, Y.; Zhou, Q.-C.; Liang, C.; Tan, Z.-L. Dietary nucleotide-rich yeast supplementation improves growth, innate immunity and intestinal morphology of Pacific white shrimp (Litopenaeus vannamei). Aquac. Nutr. 2018, 24, 1425-1435. [CrossRef]

169. Li, P.; Wang, X.; Murthy, S.; Gatlin, D.M.; Castille, F.L.; Lawrence, A.L. Effect of Dietary Supplementation of Brewer's Yeast and GroBiotic ${ }^{\circledR}$-A on Growth, Immune Responses, and Low-Salinity Tolerance of Pacific White Shrimp Litopenaeus vannamei Cultured in Recirculating Systems. J. Appl. Aquac. 2009, 21, 110-119. [CrossRef]

170. Babu, D.T.; Antony, S.P.; Joseph, S.P.; Bright, A.R.; Philip, R. Marine yeast Candida aquaetextoris S527 as a potential immunostimulant in black tiger shrimp Penaeus monodon. J. Invertebr. Pathol. 2013, 112, $243-252$. [CrossRef]

171. Nguyen, N.H.; Trinh, L.T.; Chau, D.T.; Baruah, K.; Lundh, T.; Kiessling, A. Spent brewer's yeast as a replacement for fishmeal in diets for giant freshwater prawn (Macrobrachium rosenbergii), reared in either clear water or a biofloc environment. Aquac. Nutr. 2019, 25, 970-979. [CrossRef]

172. Hai, N.V. Research findings from the use of probiotics in tilapia aquaculture: A review. Fish Shellfish Immunol. 2015, 45, 592-597. [CrossRef]

173. Ozório, R.O.A.; Portz, L.; Borghesi, R.; Cyrino, J.E.P. Effects of Dietary Yeast (Saccharomyces cerevisiae) Supplementation in Practical Diets of Tilapia (Oreochromis niloticus). Animals 2012, 2, 16-24. [CrossRef]

174. Al-Hafedh, Y.S.; Alam, A. Replacement of Fishmeal by Single Cell Protein Derived from Yeast Grown on Date (Phoenix dactylifera) Industry Waste in the Diet of Nile Tilapia (Oreochromis niloticus) Fingerlings. J. Appl. Aquac. 2013, 25, 346-358. [CrossRef]

175. Fayeofori, G.B.-M.; Bob-Manuel, F.G. A comparative study of the effect of yeast single cell protein on growth, feed utilization and condition factor of the African catfish Clarias gariepinus (Burchell) and tilapia, Oreochromis niloticus (Linnaeus) fingerlings. Afr. J. Agric. Res. 2014, 9, 2005-2011. [CrossRef]

176. Abass, D.A.; Obirikorang, K.A.; Campion, B.B.; Edziyie, R.E.; Skov, P.V. Dietary supplementation of yeast (Saccharomyces cerevisiae) improves growth, stress tolerance, and disease resistance in juvenile Nile tilapia (Oreochromis niloticus). Aquac. Int. 2018, 26, 843-855. [CrossRef]

177. Berto, R.D.S.; Pereira, G.D.V.; Mouriño, J.L.P.; Martins, M.L.; Fracalossi, D.M. Yeast extract on growth, nutrient utilization and haemato-immunological responses of Nile tilapia. Aquac. Res. 2015, 47, 2650-2660. [CrossRef] 
178. Trosvik, K.A.; Rawles, S.D.; Thompson, K.R.; Metts, L.A.; Gannam, A.; Twibell, R.; Webster, C. Growth and Body Composition of Nile Tilapia, Oreochromis niloticus, Fry Fed Organic Diets Containing Yeast Extract and Soybean Meal as Replacements for Fish Meal, with and without Supplemental Lysine and Methionine. J. World Aquac. Soc. 2012, 43, 635-647. [CrossRef]

179. Olvera-Novoa, M.; Martinez-Palacios, C.; Olivera-Castillo, L. Utilization of torula yeast (Candida utilis) as a protein source in diets for tilapia (Oreochromis mossambicus Peters) fry. Aquac. Nutr. 2002, 8, 257-264. [CrossRef]

180. Tacon, A.G.J.; Hasan, M.R.; Metian, M. Demand and supply of feed ingredients for farmed fish and crustaceans: Trends and prospects. FAO Fish. Aquac. Tech. Paper 2011, 564, 1-87.

181. Nhi, N.H.Y.; Da, C.T.; Lundh, T.; Lan, T.T.; Kiessling, A. Comparative evaluation of Brewer's yeast as a replacement for fishmeal in diets for tilapia (Oreochromis niloticus), reared in clear water or biofloc environments. Aquaculture 2018, 495, 654-660. [CrossRef]

182. Ribeiro, C.D.S.; Moreira, R.G.; Cantelmo, O.A.; Esposito, E. The use ofKluyveromyces marxianusin the diet of Red-Stirling tilapia (Oreochromis niloticus, Linnaeus) exposed to natural climatic variation: Effects on growth performance, fatty acids, and protein deposition. Aquac. Res. 2012, 45, 812-827. [CrossRef]

183. Oliva-Teles, A.; Gonçalves, P. Partial replacement of fishmeal by brewers yeast (Saccaromyces cerevisae) in diets for sea bass (Dicentrarchus labrax) juveniles. Aquaculture 2001, 202, 269-278. [CrossRef]

184. Oliva-Teles, A.; Guedes, M.; Vachot, C.; Kaushik, S. The effect of nucleic acids on growth, ureagenesis and nitrogen excretion of gilthead sea bream Sparus aurata juveniles. Aquaculture 2006, 253, 608-617. [CrossRef]

185. Li, P.; Gatlin, D.M. Evaluation of brewers yeast (Saccharomyces cerevisiae) as a feed supplement for hybrid striped bass (Morone chrysops $\times$ M. saxatilis). Aquaculture 2003, 219, 681-692. [CrossRef]

186. Rosas, V.T.; Poersch, L.; Romano, L.A.; Tesser, M.B. Feasibility of the use of Spirulina in aquaculture diets. Rev. Aquac. 2018, 11, 1367-1378. [CrossRef]

187. Belay, A.; Kato, T.; Ota, Y. Spirulina (Arthrospira): Potential application as an animal feed supplement. J. Appl. Phycol. 1996, 8, 303-311. [CrossRef]

188. Matassa, S.; Boon, N.; Pikaar, I.; Verstraete, W. Microbial protein: Future sustainable food supply route with low environmental footprint. Microb. Biotechnol. 2016, 9, 568-575. [CrossRef] [PubMed]

189. Perera, W.M.K.; Carter, C.G.; Houlihan, D.F. Apparent absorption efficiencies of amino acids in rainbow trout, Oncorhynchus mykiss (Walbaum), fed diets containing bacterial single-cell protein. Aquac. Nutr. 1995, 1, 95-103. [CrossRef]

190. Aas, T.S.; Hatlen, B.; Grisdale-Helland, B.; Terjesen, B.F.; Bakke-McKellep, A.M.; Helland, S.J. Effects of diets containing a bacterial protein meal on growth and feed utilisation in rainbow trout (Oncorhynchus mykiss). Aquaculture 2006, 261, 357-368. [CrossRef]

191. Kiessling, A.; Askbrandt, S. Nutritive value of two bacterial strains of single-cell protein for rainbow trout (Oncorhynchus mykiss). Aquaculture 1993, 109, 119-130. [CrossRef]

192. Berge, G.M.; Baeverfjord, G.; Skrede, A.; Storebakken, T. Bacterial protein grown on natural gas as protein source in diets for Atlantic salmon, Salmo salar, in saltwater. Aquaculture 2005, 244, 233-240. [CrossRef]

193. Teimouri, M.; Amirkolaie, A.K.; Yeganeh, S. The effects of Spirulina platensis meal as a feed supplement on growth performance and pigmentation of rainbow trout (Oncorhynchus mykiss). Aquaculture 2013, 396, 14-19. [CrossRef]

194. Hanel, R.; Broekman, D.; De Graaf, S.; Schnack, D. Partial Replacement of Fishmeal by Lyophylized Powder of the Microalgae Spirulina platensis in Pacific White Shrimp Diets. Open Mar. Biol. J. 2007, 1, 1-5. [CrossRef]

195. Silva-Neto, J.F.; Nunes, A.J.P.; Sabry-Neto, H.; Sá, M.V.C. Spirulina meal has acted as a strong feeding attractant for Litopenaeus vannamei at a very low dietary inclusion level. Aquac. Res. 2012, 43, 430-437. [CrossRef]

196. Macias-Sancho, J.; Poersch, L.H.; Bauer, W.; Romano, L.A.; Wasielesky, W.; Tesser, M.B. Fishmeal substitution with Arthrospira (Spirulina platensis) in a practical diet for Litopenaeus vannamei: Effects on growth and immunological parameters. Aquaculture 2014, 426, 120-125. [CrossRef]

197. Hamidoghli, A.; Yun, H.; Won, S.; Kim, S.; Farris, N.W.; Bai, S.C. Evaluation of a single-cell protein as a dietary fish meal substitute for whiteleg shrimp Litopenaeus vannamei. Fish. Sci. 2018, 85, 147-155. [CrossRef]

198. Imelda, J.; Paulraj, R. Efficacy of bacterial fermented oilcake mix as fishmeal substitute in the diet of tiger shrimp, Penaeus monodon (Fabricius) post larvae. Indian J. Fish. 2007, 54, 379-387.

199. Hamidoghli, A.; Won, S.; Farris, N.W.; Bae, J.; Choi, W.; Yun, H.; Bai, S.C. Solid state fermented plant protein sources as fish meal replacers in whiteleg shrimp Litopaeneus vannamei. Anim. Feed Sci. Technol. 2020, 264, 114474. [CrossRef] 
200. Velasquez, S.F.; Chan, M.A.; Abisado, R.G.; Traifalgar, R.F.M.; Tayamen, M.M.; Maliwat, G.C.F.; Ragaza, J.A. Dietary Spirulina (Arthrospira platensis) replacement enhances performance of juvenile Nile tilapia (Oreochromis niloticus). J. Appl. Phycol. 2016, 28, 1023-1030. [CrossRef]

201. Aas, T.S.; Hatlen, B.; Grisdale-Helland, B.; Terjesen, B.F.; Penn, M.; Bakke-McKellep, A.M.; Helland, S.J. Feed intake, growth and nutrient utilization in Atlantic halibut (Hippoglossus hippoglossus) fed diets containing a bacterial protein meal. Aquac. Res. 2007, 38, 351-360. [CrossRef]

202. Shapawi, R.; Ting, T.E.; Al-Azad, S. Inclusion of Purple Non-sulfur Bacterial Biomass in Formulated Feed to Promote Growth, Feed Conversion Ratio and Survival of Asian Seabass Lates calcarifer Juveniles. J. Fish. Aquat. Sci. 2012, 7, 475-480. [CrossRef]

203. Deboutteville, J.D.; Batstone, D.J.; Kawasaki, M.; Stegman, S.; Salini, M.; Tabrett, S.; Smullen, R.; Barnes, A.; Hülsen, T. Mixed culture purple phototrophic bacteria is an effective fishmeal replacement in aquaculture. Water Res. X 2019, 4, 100031. [CrossRef]

204. Bauer, W.; Prentice-Hernández, C.; Tesser, M.B.; Wasielesky, W., Jr.; Poersch, L.H. Substitution of fishmeal with microbial floc meal and soy protein concentrate in diets for the pacific white shrimp Litopenaeus vannamei. Aquaculture 2012, 342, 112-116. [CrossRef]

205. Arnold, S.J.; Smullen, R.; Briggs, M.; West, M.; Glencross, B. The combined effect of feed frequency and ration size of diets with and without microbial biomass on the growth and feed conversion of juvenile Penaeus monodon. Aquac. Nutr. 2015, 22, 1340-1347. [CrossRef]

206. Ju, Z.Y.; Forster, I.; Conquest, L.; Dominy, W. Enhanced growth effects on shrimp (Litopenaeus vannamei) from inclusion of whole shrimp floc or floc fractions to a formulated diet. Aquac. Nutr. 2008, 14, 533-543. [CrossRef]

207. Kuhn, D.D.; Lawrence, A.L.; Boardman, G.D.; Patnaik, S.; Marsh, L.; Flick, G.J. Evaluation of two types of bioflocs derived from biological treatment of fish effluent as feed ingredients for Pacific white shrimp, Litopenaeus vannamei. Aquaculture 2010, 303, 28-33. [CrossRef]

208. Azim, M.; Little, D. The biofloc technology (BFT) in indoor tanks: Water quality, biofloc composition, and growth and welfare of Nile tilapia (Oreochromis niloticus). Aquaculture 2008, 283, 29-35. [CrossRef]

209. Azim, M.; Little, D.; Bron, J.E. Microbial protein production in activated suspension tanks manipulating C:N ratio in feed and the implications for fish culture. Bioresour. Technol. 2008, 99, 3590-3599. [CrossRef] [PubMed]

210. Simon, C.J.; Blyth, D.; Fatan, N.A.; Suri, S.K. Microbial biomass (Novacq ${ }^{\mathrm{TM}}$ ) stimulates feeding and improves the growth performance on extruded low to zero-fishmeal diets in tilapia (GIFT strain). Aquaculture 2019, 501, 319-324. [CrossRef]

211. Suphantharika, M. Preparation of spent brewer's yeast $\beta$-glucans with a potential application as an immunostimulant for black tiger shrimp, Penaeus monodon. Bioresour. Technol. 2003, 88, 55-60. [CrossRef]

212. Romarheim, O.H.; Øverland, M.; Mydland, L.T.; Skrede, A.; Landsverk, T. Bacteria Grown on Natural Gas Prevent Soybean Meal-Induced Enteritis in Atlantic Salmon. J. Nutr. 2010, 141, 124-130. [CrossRef]

213. Romarheim, O.H.; Landsverk, T.; Mydland, L.T.; Skrede, A.; Øverland, M. Cell wall fractions from Methylococcus capsulatus prevent soybean meal-induced enteritis in Atlantic salmon (Salmo salar). Aquaculture 2013, 402, 13-18. [CrossRef]

214. Lyons, P.P.; Turnbull, J.; Dawson, K.A.; Crumlish, M. Effects of low-level dietary microalgae supplementation on the distal intestinal microbiome of farmed rainbow trout Oncorhynchus mykiss (Walbaum). Aquac. Res. 2016, 48, 2438-2452. [CrossRef]

215. Reyes-Becerril, M.; Guardiola, F.; Rojas, M.; Ascencio, F.; Esteban, M. Ángeles Dietary administration of microalgae Navicula sp. affects immune status and gene expression of gilthead seabream (Sparus aurata). Fish Shellfish. Immunol. 2013, 35, 883-889. [CrossRef]

216. Burgents, J.E.; Burnett, K.G.; Burnett, L.E. Disease resistance of Pacific white shrimp, Litopenaeus vannamei, following the dietary administration of a yeast culture food supplement. Aquaculture 2004, 231, 1-8. [CrossRef]

217. Sahlmann, C.; Djordjevic, B.; Lagos, L.; Mydland, L.T.; Morales-Lange, B.; Hansen, J.Ø.; Ånestad, R.; Mercado, L.; Bjelanovic, M.; Press, C.M.; et al. Yeast as a protein source during smoltification of Atlantic salmon (Salmo salar L.), enhances performance and modulates health. Aquaculture 2019, 513. [CrossRef]

218. Vasanth, G.; Viswanath, K.; Kulkarni, A.; Dahle, D.; Lokesh, J.; Kitani, Y. A Microbial Feed Additive Abates Intestinal Inflammation in Atlantic Salmon. Front. Immunol. 2015, 6, 409. [CrossRef] 
219. Grassi, T.L.M.; Oliveira, D.L.; Paiva, N.M.; Diniz, J.C.P.; Bosco, A.M.; Pereira, A.A.F.; Menezes, A.R.P.; Valadares, T.C.; Pastor, R.C.P.; Ciarlini, P.C.; et al. Microbial biomass as an antioxidant for tilapia feed. Aquac. Res. 2018, 49, 2881-2890. [CrossRef]

220. Zhao, P.; Huang, J.; Wang, X.H.; Song, X.L.; Yang, C.H.; Zhang, X.G.; Wang, G.C. The application of bioflocs technology in high-intensive, zero exchange farming systems of Marsupenaeus japonicus. Aquaculture 2012, 354, 97-106. [CrossRef]

221. Samuelsen, T.A.; Oterhals, Å.; Kousoulaki, K. High lipid microalgae (Schizochytrium sp.) inclusion as a sustainable source of $\mathrm{n}-3$ long-chain PUFA in fish feed-Effects on the extrusion process and physical pellet quality. Anim. Feed Sci. Technol. 2018, 236, 14-28. [CrossRef]

222. Øverland, M.; Romarheim, O.H.; Ahlstrøm, Ø.; Storebakken, T.; Skrede, A. Technical quality of dog food and salmon feed containing different bacterial protein sources and processed by different extrusion conditions. Anim. Feed Sci. Technol. 2007, 134, 124-139. [CrossRef]

223. Lu, J.; Takeuchi, T.; Ogawa, H. Flesh quality of tilapia Oreochromis niloticus fed solely on raw Spirulina. Fish. Sci. 2003, 69, 529-534. [CrossRef]

224. Lopes da Silva, T.; Moniz, P.; Silva, C.; Reis, A. The Dark Side of Microalgae Biotechnology: A Heterotrophic Biorefinery Platform Directed to $\omega$-3 Rich Lipid Production. Microorganisms 2019, 7, 670. [CrossRef]

225. Sillman, J.; Nygren, L.; Kahiluoto, H.; Ruuskanen, V.; Tamminen, A.; Bajamundi, C.; Nappa, M.; Wuokko, M.; Lindh, T.; Vainikka, P.; et al. Bacterial protein for food and feed generated via renewable energy and direct air capture of $\mathrm{CO}_{2}$ : Can it reduce land and water use? Glob. Food Secur. 2019, 22, 25-32. [CrossRef]

226. Ketzer, F.; Skarka, J.; Rösch, C. Critical Review of Microalgae LCA Studies for Bioenergy Production. BioEnergy Res. 2017, 11, 95-105. [CrossRef]

227. Guedes, A.C.; Pinto, I.S.; Malcata, F. Application of Microalgae Protein to Aquafeed. In Handbook of Marine Microalgae; Academic Press: London, UK, 2015; pp. 93-125.

228. Chauton, M.S.; Reitan, K.I.; Norsker, N.H.; Tveteras, R.; Kleivdal, H.T. A techno-economic analysis of industrial production of marine microalgae as a source of EPA and DHA-rich raw material for aquafeed: Research challenges and possibilities. Aquaculture 2015, 436, 95-103. [CrossRef]

(C) 2020 by the authors. Licensee MDPI, Basel, Switzerland. This article is an open access article distributed under the terms and conditions of the Creative Commons Attribution (CC BY) license (http://creativecommons.org/licenses/by/4.0/). 